\title{
Size-resolved measurements of brown carbon in water and methanol extracts and estimates of their contribution to ambient fine-particle light absorption
}

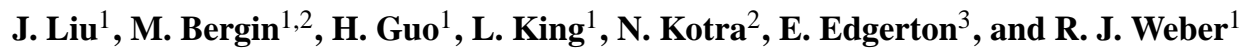 \\ ${ }^{1}$ School of Earth and Atmospheric Sciences, Georgia Institute of Technology, Atlanta, GA, USA \\ ${ }^{2}$ School of Civil \& Environmental Engineering, Georgia Institute of Technology, Atlanta, GA, USA \\ ${ }^{3}$ Atmospheric Research and Analysis, Inc, Cary, N.C., USA \\ Correspondence to: R. Weber (rodney.weber@eas.gatech.edu)
}

Received: 3 June 2013 - Published in Atmos. Chem. Phys. Discuss.: 9 July 2013

Revised: 5 November 2013 - Accepted: 6 November 2013 - Published: 19 December 2013

\begin{abstract}
Light absorbing organic carbon, often called brown carbon, has the potential to significantly contribute to the visible light-absorption budget, particularly at shorter wavelengths. Currently, the relative contributions of particulate brown carbon to light absorption, as well as the sources of brown carbon, are poorly understood. With this in mind size-resolved direct measurements of brown carbon were made at both urban (Atlanta), and rural (Yorkville) sites in Georgia. Measurements in Atlanta were made at both a representative urban site and a road-side site adjacent to a main highway. Fine particle absorption was measured with a multiangle absorption photometer (MAAP) and seven-wavelength Aethalometer, and brown carbon absorption was estimated based on Mie calculations using direct size-resolved measurements of chromophores in solvents. Size-resolved samples were collected using a cascade impactor and analyzed for water-soluble organic carbon (WSOC), organic and elemental carbon (OC and EC), and solution light-absorption spectra of water and methanol extracts. Methanol extracts were more light-absorbing than water extracts for all size ranges and wavelengths. Absorption refractive indices of the organic extracts were calculated from solution measurements for a range of wavelengths and used with Mie theory to predict the light absorption by fine particles comprised of these components, under the assumption that brown carbon and other aerosol components were externally mixed. For all three sites, chromophores were predominately in the accumulation mode with an aerodynamic mean diameter of $0.5 \mu \mathrm{m}$, an optically effective size range resulting in predicted
\end{abstract}

particle light absorption being a factor of 2 higher than bulk solution absorption. Mie-predicted brown carbon absorption at $350 \mathrm{~nm}$ contributed a significant fraction (20 to $40 \%$ ) relative to total light absorption, with the highest contributions at the rural site where organic to elemental carbon ratios were highest. Brown carbon absorption, however, was highest by the roadside site due to vehicle emissions. The direct sizeresolved measurement of brown carbon in solution definitively shows that it is present and optically important in the near-UV range in both a rural and urban environment during the summer when biomass burning emissions are low. These results allow estimates of brown carbon aerosol absorption from direct measurements of chromophores in aerosol extracts.

\section{Introduction}

Light absorbing components of atmospheric aerosols influence the planetary radiation budget and climate by direct absorption of radiation and through secondary routes that include influences on cloud optics and dynamics, and snow or ice albedo (Bond et al., 2013). Uncertainties associated with light absorbing aerosol forcing contribute to uncertainty in climate change estimates (IPCC, 2007). Black carbon (BC), largely comprised of elemental carbon (EC), is the strongest of the light-absorbing aerosol components (Bond, 2001; Moosmuller et al., 2009, and references therein). Other absorbing components include mineral dust (e.g., hematite) 
(Sokolik and Toon, 1999) and certain, mostly unidentified (Zhang et al., 2013), constituents of organic matter. Both, preferentially absorb radiation in the lower visible to nearUV wavelength range due to a wavelength-dependent imaginary component of the refractive index. As a group, lightabsorbing organic aerosols have been referred to as brown carbon (Andreae and Gelencser, 2006).

Brown carbon has both primary and secondary sources. Particles from incomplete and smoldering combustion of hydrocarbons, especially those associated with biomass or biofuel burning, can contain substantial amounts of brown carbon (Chakrabarty et al., 2010; Hoffer et al., 2006; Kirchstetter et al., 2004; Kirchstetter and Thatcher, 2012; Lack et al., 2012; Lukacs et al., 2007; Qin and Mitchell, 2009; Hecobian et al., 2010). Brown carbon also has secondary sources (e.g., Andreae and Gelencser, 2006; Chakrabarty et al., 2010; Chen and Bond, 2010; Nakayama et al., 2010; Sareen et al., 2010; Shapiro et al., 2009; Bones et al., 2010; Bateman et al., 2011; Nguyen et al., 2012; de Haan et al., 2009; Zhang et al., 2011, 2013). Laboratory studies show the production of brown carbon through a variety of formation processes, such as low-temperature oxidation of biogenic materials (e.g., lignin) and their polymerization products, reactions of organic compounds in acidic solutions (Sareen et al., 2010), heterogeneous reactions from dienes like isoprene in the presence of sulfuric acid (Limbeck et al., 2003), and a variety of additional aqueous phase reactions (Updyke et al., 2012; Chang and Thompson, 2010).

The mass absorption efficiency of brown carbon increases rapidly from long to shorter wavelengths (Alexander et al., 2008), beginning to absorb near the middle of the visible spectrum $(550 \mathrm{~nm})$. Attenuation of ultraviolet radiation by brown carbon may, in certain situations, suppress photochemistry (Jacobson, 1999; Bahadur et al., 2012) and some studies have suggested brown carbon could affect the planetary radiation balance and climate by direct absorption (Bahadur et al., 2012; Chung et al., 2012; Feng et al., 2013; Park et al., 2010), or through dissolution into cloud droplets resulting in homogeneous absorbing droplets (Fuzzi et al., 2006).

Measuring spectrophotometric properties of aerosol water or filter extracts is a highly sensitive approach to quantify the presence of brown carbon (Hecobian et al., 2010; Kieber et al., 2006; Lukacs et al., 2007; Zhang et al., 2011). Two years of filter extract measurements in Europe showed brown carbon mainly associated with biomass burning tracers (Lukacs et al., 2007). Kieber et al. (2006) found that chromphores were ubiquitous in rainwater collected in the southeastern US and concluded they were associated with continental sources. Brown carbon was also found in $\mathrm{PM}_{2.5}$ particles throughout the southeastern US, where the light-absorbing fraction of water-soluble organic carbon (WSOC) was mainly related to biomass burning in winter and apparently secondary sources during summer (Hecobian et al., 2010; Zhang et al., 2011). Secondary sources of brown carbon are especially prevalent in urban environments with high anthropogenic emissions.
Water-extract mass absorption efficiencies (absorption of water soluble carbon at $365 \mathrm{~nm}$ per WSOC mass concentration) were 6 to 7 times higher in Los Angeles compared to Atlanta (Zhang et al., 2011), the former an urban environment dominated by anthropogenic SOA. These studies of brown carbon in aerosol extracts (solutions) have identified the ubiquitous extent of fine particle brown carbon and explored their sources and chemistry, but do not address the possible optical importance.

Optical instruments that measure particle light-absorption coefficients $\left(b_{\mathrm{ap}}\right.$, a nomenclature list is provided in Appendix A) typically operate at a limited number of wavelengths and quantify the "total" absorption, which depending on emissions includes varying proportions of black carbon (BC), brown carbon and mineral dust (Sandradewi et al., 2008). Quantifying brown carbon by difference can be difficult due to the typically large contribution of BC. Particle morphology can also complicate the measurement of brown carbon, such as possible amplifying of BC absorption by lensing effects involving scattering shells over absorbing cores (Bond et al., 2006; Cappa et al., 2012; Lack and Cappa, 2010). In contrast, light absorption measured from liquid extracts does not suffer from interference by BC or other absorbers, since they can be isolated by dissolution, thereby permitting a direct measurement of brown carbon. Spectrophotometers that measure soluble brown carbon can also provide highly spectrally resolved data $(1 \mathrm{~nm}$ wavelength resolution) over wide wavelength ranges (e.g., 200 to $900 \mathrm{~nm}$ ), an advantage over several fixed wavelengths associated with optical instruments (Hecobian et al., 2010). Furthermore, when combined with a long-path absorption cell, spectrophotometry of aerosol extract solutions is a highly sensitive measurement. By performing size-resolved measurements of brown carbon and using the bulk solution lightabsorption measurements to estimate the absorbing refractive index, we investigate the optical importance of water and methanol-soluble brown carbon absorption predicted with the Mie theory and compare it to measurements of $\mathrm{BC}$ made with standard optical instruments.

\section{Methods}

\subsection{Sampling sites}

Sampling was carried out at several sites in and around Atlanta, GA. This included two SEARCH (southeastern Research and Characterization Experiment) sites (Hansen et al., 2006); Jefferson Street (JST), an urban site not significantly influenced by any strong local sources, and Yorkville (YRK), the SEARCH rural pair to JST located approximately $80 \mathrm{~km}$ west (generally upwind) of Atlanta. A third RoadSide site (RS), was situated within $2 \mathrm{~m}$ of a major roadway in central Atlanta (interstates 75 and 85, 8 lanes each direction) that has restricted heavy-duty diesel truck access 
Table 1. Mean and standard deviation of parameters measured with online instruments (except for EC) during MOUDI sampling periods at various sites.

\begin{tabular}{|c|c|c|c|c|c|c|c|c|c|c|}
\hline $\begin{array}{l}\text { Start } \\
\text { time }\end{array}$ & $\begin{array}{l}\text { Stop } \\
\text { time }\end{array}$ & Location & $\begin{array}{c}\text { Temperature, } \\
{ }^{\circ} \mathrm{C}\end{array}$ & $\begin{array}{c}\mathrm{RH}, \\
\%\end{array}$ & $\begin{array}{l}\mathrm{PM}_{2.5}, \\
\mu \mathrm{g} \mathrm{m}^{-3}\end{array}$ & $\begin{array}{c}\mathrm{OC}, \\
\mu \mathrm{gC} \mathrm{m}^{-3}\end{array}$ & $\begin{array}{c}\mathrm{EC}^{*}, \\
\mu \mathrm{gC} \mathrm{m}^{-3}\end{array}$ & $\begin{array}{l}\mathrm{OC} / \mathrm{EC}^{*} \\
\text { ratio }\end{array}$ & $\begin{array}{c}\text { BC (Avg of, } \\
\text { all Aeth. } \lambda \text { ) } \\
\mu \mathrm{gC} \mathrm{m}^{-3}\end{array}$ & $\begin{array}{c}\text { WSOC, } \\
\mu \mathrm{gC} \mathrm{m}^{-3}\end{array}$ \\
\hline $5 / 17 / 12,16: 45$ & $5 / 20 / 12,15: 00$ & JST & $22.5 \pm 3.5$ & $55.2 \pm 13.3$ & 14.63 & 4.39 & 0.81 & 5.4 & 0.77 & 2.38 \\
\hline $5 / 25 / 12,12: 00$ & $5 / 27 / 12,20: 00$ & JST & $28.6 \pm 3.4$ & $46.8 \pm 11.4$ & 18.96 & 4.61 & 0.82 & 5.6 & 0.93 & 2.89 \\
\hline $6 / 15 / 12,11: 35$ & $6 / 18 / 12,13: 30$ & YRK & $23.8 \pm 3.4$ & $55.7 \pm 12.6$ & 10.70 & 4.43 & 0.38 & 11.7 & 0.45 & 2.44 \\
\hline $6 / 21 / 12,11: 10$ & $6 / 23 / 12,11: 50$ & YRK & $27.2 \pm 3.1$ & $57.8 \pm 11.7$ & 16.09 & 5.24 & 0.44 & 11.9 & 0.44 & 2.72 \\
\hline $6 / 27 / 12,12: 00$ & $6 / 29 / 12,13: 55$ & YRK & $28.9 \pm 4.5$ & $44.2 \pm 15.1$ & 17.73 & 7.26 & 0.54 & 13.4 & 0.55 & 4.36 \\
\hline $9 / 26 / 12,12: 00$ & $9 / 29 / 12,8: 40$ & RS & $24.0 \pm 3.7$ & $58.3 \pm 16.8$ & 13.36 & 6.66 & 1.42 & 4.7 & NAN & 2.99 \\
\hline
\end{tabular}

$*$ EC data from MOUDI filter measurements since online thermal EC data were not available due to instrument issues.

(Georgia Department of Transportation estimates approximately 320000 vehicles per day, with 16000 trucks; also see Yan et al., 2011, and references therein). At all three sites, measurements were made with a suite of online and offline instruments that were moved from site-to-site during the summer and fall of 2012.

\subsection{Offline measurements}

A 10 stage Micro-Orifice Uniform Deposit Impactor (MOUDI, MSP Corp., Shoreview, MN, USA) operated in non-rotating mode was used to collect size-resolved aerosols for subsequent analysis. Theoretical MOUDI 50\% aerodynamic diameter cut sizes of the stages are 10.00, 6.20, 3.10, $1.80,1.00,0.62,0.31,0.18,0.10$, and $0.056 \mu \mathrm{m}$. The impactors are followed by an after filter. All MOUDI samplers were located outside so that particle size selection occurred at ambient temperature and RH. The samples were collected onto impaction plates of prebaked $47 \mathrm{~mm}$ quartz filters (Pall Life Sciences, Ann Arbor, MI) at a flow rate of nominally $30 \mathrm{~L} \mathrm{~min}^{-1}$ for roughly $60 \mathrm{~h}$. A punch from each filter was taken for the analysis of OC and EC, and the remaining portion was divided into two halves, one extracted in high purity water the other methanol. Since the MOUDI was not operated in rotation mode during sampling, the non-uniformity of deposits on the quartz impaction filters was accounted for when dividing the filters for subsequent analysis by counting deposits from each jet, for stages of cut size $0.31 \mu \mathrm{m}$ and up. For stages below, the deposits were considered uniform and the fraction of the filter analyzed was determined from fractional area. In all, six complete MOUDI samples were collected under sunny, precipitation free periods, summarized in Table 1. For every sample run, two quartz filter field blanks were included and data were blank corrected.

Organic carbon (OC) and elemental carbon (EC) were quantified with a Sunset OCEC Analyzer (Sunset Laboratory Inc., Tigard, OR) following the NIOSH protocol (NIOSH, 1996). In this analysis, non-uniform MOUDI deposits hinder the optical determination of OC / EC split based on laser attenuation, so a specified split of $500 \mathrm{~s}$ (corresponding temperature of $700^{\circ} \mathrm{C}$ ) was used based on the temperature split determined by the standard thermal-optical transmittance method (i.e., laser signal reaches its initial value) from regular quartz filter samples collected during the study period. $\mathrm{OC}$ and $\mathrm{EC}$ blanks ranged from 0.03 to $0.1 \mu \mathrm{gC} \mathrm{m}^{-3}$, and below limit of detection (LOD) to $0.003 \mu \mathrm{gC} \mathrm{m}^{-3}$, respectively, with uncertainties estimated as $13 \%$ for OC and $16 \%$ for EC based on blank variability $(1 \sigma)$, uncertainties in flow rates and $\mathrm{OC} / \mathrm{EC}$ split determination (various measurement uncertainties are summarized in Table 2).

Halved quartz impaction plates and after filters were extracted in high purity water (>18 Mohm) and methanol (VWR International, A.C.S. Grade), by $30 \mathrm{~min}$ of sonication. All extracts were then filtered through a $25 \mathrm{~mm}$ diameter $0.45 \mu \mathrm{m}$ pore syringe filter (Fisher Scientific, Fisherbrand* Syringe Filters) to remove insoluble components and filter remnants generated during the extraction process. Water extracts were transferred into a coupled LWCC-TOC (Liquid Waveguide Capillary Cell-Total Organic Carbon) system to determine the water-soluble light-absorption spectra and water-soluble organic carbon (WSOC) mass following the method by Hecobian et al. (2010). LOD of watersoluble brown carbon at $365 \mathrm{~nm}$ was $0.031 \mathrm{Mm}^{-1}$ and for WSOC $0.084 \mu \mathrm{gC} \mathrm{m}^{-3}$, with estimated uncertainties of $21 \%$ and $9 \%$, respectively, mainly due to blank variability $(1 \sigma)$.

For the methanol extracts, only light-absorption spectra were analyzed (i.e., methanol soluble brown carbon) since the use of an organic solvent prohibits determining carbon mass (TOC) in these solutions. Estimated LOD for methanolsoluble brown carbon at $365 \mathrm{~nm}$ is $0.11 \mathrm{Mm}^{-1}$ with an uncertainty of $27 \%$ due to blank variability $(1 \sigma)$.

\subsection{Online measurements: MAAP, Aethalometer, OC, EC, WSOC, water-soluble brown carbon and TEOM (PM 2.5$)$}

A suite of online measurements were made at the same time and location as the MOUDIs as part of another study (EPASCAPE), which included $\mathrm{PM}_{2.5}$ mass by TEOM, Sunset Labs OC and EC, PILS-WSOC and water-soluble absorption, and $\mathrm{BC}$ measured by a multi-angle absorption photometer (MAAP) and 7-wavelength Aethalometer. The OCEC, 
Table 2. Summary of estimated uncertainties for various species reported. In all cases where variability was used to estimate an uncertainty, 1 standard deviation is used.

\begin{tabular}{|c|c|c|}
\hline Instruments/analysis & Species measured/reported & Uncertainty, \% \\
\hline Sunset OC EC & OC (offline/online) ${ }^{1}$ & $13 / 28$ \\
\hline Sunset OC EC & $\mathrm{EC}$ (offline) $)^{2}$ & 16 \\
\hline TOC & WSOC (offline/online) ${ }^{3}$ & $9 / 7$ \\
\hline LWCC-Spectrophotometer & $\mathrm{H}_{2} \mathrm{O} \_\mathrm{Abs}(365)$ (offline/online) $)^{4}$ & $21 / 20$ \\
\hline LWCC-Spectrophotometer & $\mathrm{MeOH} \_\mathrm{Abs}(365)^{5}$ & 27 \\
\hline TEOM (1 h) & $\mathrm{PM}_{2.5}$ mass & 30 \\
\hline MAAP & $\mathrm{BC}$ or $b_{\mathrm{ap} \_\mathrm{MAAP}}^{6}$ & 12 \\
\hline Aethalometer & $\mathrm{BC}^{6}$ & 4 \\
\hline Scattering correction & Aeth $\mathrm{BC} \mathrm{b}_{\mathrm{ap}}^{7}$ & 35 \\
\hline Mie calculation & $b_{\mathrm{ap}}$ of $\mathrm{EC}$ and $\mathrm{BrnC}^{8}$ & 30 \\
\hline \multicolumn{3}{|c|}{ Combined uncertainties in calculated parameters } \\
\hline$b_{\text {ap_Aeth }}^{9}$ & & 36 \\
\hline$b_{\mathrm{ap} \_\mathrm{EC}}^{10}$ & & 34 \\
\hline$b_{\mathrm{ap}, \mathrm{H}_{2} \mathrm{O}}(\text { at } 365 \mathrm{~nm})^{11}$ & & 38 \\
\hline$b_{\mathrm{ap}, \mathrm{MeOH}}(\text { at } 365 \mathrm{~nm})^{12}$ & & 42 \\
\hline $\mathrm{H}_{2} \mathrm{O} \_$brnC ratio $^{13}$ & relative to $b_{\text {ap_Aeth }} / b_{\text {ap_EC }}$ & $52 / 51$ \\
\hline $\mathrm{MeOH} \_b r n C$ ratio $^{14}$ & relative to $b_{\text {ap_Aeth }} / b_{\text {ap_EC }}$ & $56 / 54$ \\
\hline
\end{tabular}

1,2 Uncertainty calculated as quadrature sum of relative errors in: filter sampling air volume (flow rate $\times$ sampling time), blank filters, field blanks, standard deviation from duplicate measurements on same filter, and uncertainties associated with the OC/EC split determination.

${ }^{3}$ Uncertainty includes relative errors in: filter sampling air volume (flow rate $\times$ sampling time), liquid volume of solvents, solvent blanks, field blanks, the variability in calibration standards, and standard deviation from duplicate standards.

4,5 Uncertainty includes relative errors in: filter sampling air volume (flow rate $\times$ sampling time), liquid volume of solvents, solvent blanks, field blanks, and standard deviation from duplicate samples.

${ }^{6}$ Uncertainty includes uncertainty of instrument reported by manufacture and variation in flow rates.

${ }^{7}$ Uncertainty estimated by combining uncertainties of all factors in scattering correction.

8 Relative uncertainty associated with variables used in the Mie calculation, including that aerosols in each stage were assumed to have the same size, the selection of organic mass vs. particle mass, real part of the refractive index, and sensitivity to density $(\rho)$, both in Mie calculation and conversion from MOUDI aerodynamic sizes to physical sizes.

${ }^{9}$ Combined uncertainty of 6 , and 7. ${ }^{10}$ Combined uncertainty of 2 and 8 .

${ }^{11}$ Combined uncertainty of 3,4 , and $8 .{ }^{12}$ Combined uncertainty of 1,5 , and 8

13 Combined uncertainty of 10 and $11 .{ }^{14}$ Combined uncertainty of 10 and 12 .

WSOC and solution light absorption were measured via identical methods to the offline analysis of the MOUDI samples (except, a $1 \mathrm{~m}$ path length LWCC was used for the online system vs. a $2.5 \mathrm{~m}$ path length LWCC for the offline analysis, World Precision Instruments).

The TEOM (Thermo Scientific, model 1400a) was operated at a temperature of $30^{\circ} \mathrm{C}$ with a Nafion dryer (Perma Pure, Toms River, NJ) upstream of the sensor, which reduced the RH to below $40 \%$. The detection limit and measurement uncertainty is estimated as $0.5 \mu \mathrm{g} \mathrm{m}^{-3}$ and $30 \%$ (for an hourly average), respectively.

$\mathrm{PM}_{2.5}$ OC and EC were determined with a Sunset Labs OC / EC analyzer (Model 3F, Forest Grove, OR), which operated at a $45 \mathrm{~min}$ sampling period followed by $15 \mathrm{~min}$ of analysis. A parallel plate carbon denuder (Eatough et al., 1993) upstream of the instrument was installed to reduce positive sampling artifacts from volatile gases. Systematic blank measurements were made throughout the study period by in- stalling a Teflon filter ( $47 \mathrm{~mm}$ diameter, $2.0 \mu \mathrm{m}$ pore size, Pall Life Sciences) on the cyclone inlet on a daily basis. A linear interpolation was applied between consecutive blanks and blanks subtracted from the ambient data. OC blanks ranged from 0.44 to $1.05 \mu \mathrm{gC} \mathrm{m}^{-3}$ and optical EC blanks varied from 0.02 to $0.03 \mu \mathrm{gC} \mathrm{m}^{-3}$. Uncertainty due to random measurement errors is estimated to be $28 \%$.

The measurement of online WSOC and light absorption was provided by a PILS-LWCC-TOC system. A ParticleInto-Liquid Sampler (PILS) that continuously transfers ambient $\mathrm{PM}_{2.5}$ aerosol to an aqueous flow of purified water was coupled in series with a long-path UV/VIS spectrophotometer (DT-Mini-2 light source and USB4000 spectrometer, both from Ocean Optics, Dunedin, FL) for measurement of soluble aerosol light-absorption spectra $(200-800 \mathrm{~nm})$, followed by a TOC analyzer to obtain the WSOC concentration, similar to the method of Hecobian et al. (2010). PILS-generated liquid sample was filtered with a Whatman $25 \mathrm{~mm}$ filter 
(Puradisc Disposable Syringe Filters, $0.2 \mu \mathrm{m}$ core size) to remove any insoluble aerosol components larger than $0.2 \mu \mathrm{m}$. Complete absorption spectra $(200-800 \mathrm{~nm})$ were recorded every $15 \mathrm{~min}$. Every three days, the LWCC was cleaned using $0.6 \mathrm{~N}$ solution of $\mathrm{HCl}$ and Milli-Q (> $18 \mathrm{M} \Omega$ ) DI water. Following cleaning, the baseline was zeroed using the Spectra-Suite software so that zero absorption was recorded at all wavelengths for milli-Q (>18 M $\Omega$ ) DI water, or pure methanol solvent (only for offline determination). For the offline system, this cleaning and zeroing was done prior to every sample. Similar to online OCEC measurement, an automated valve that directed sample air-flow through a Teflon filter performed dynamic blanks three times every day and a linear interpolation between successive blanks was assumed to blank correct the online measurements. Instrument LOD and measurement uncertainty are estimated at $0.20 \mu \mathrm{gC} \mathrm{m} \mathrm{m}^{-3}$ and $7 \%$ for WSOC, $0.1 \mathrm{Mm}^{-1}$ and $20 \%$ for water-soluble absorption at $365 \mathrm{~nm}$, respectively.

Online black carbon (BC) was measured with an Aethalometer (Magee Scientific, Berkeley, CA) and MAAP (Thermo-Scientific model 5012), both based on measurements of light attenuation through a particle-laden filter. The Aethalometer operates at seven wavelengths covering the ultra-violet to the near-infrared wavelength range (370, 450, $571,590,660,880$, and $950 \mathrm{~nm}$ ). Data interpretation requires scattering corrections, which are discussed further below. The MAAP operates at a single wavelength of $670 \mathrm{~nm}$ and is designed to account for scattering error when measuring $\mathrm{BC}$; no corrections are applied in this case. MAAP $b_{\text {ap }}$ uncertainty is estimated at $12 \%$ (Petzold and Schönlinner, 2004). (Aethalometer measurement uncertainties are discussed below). The MAAP was operated only at the JST site and the Aethalometer was operational only at the JST and YRK sites.

\subsection{Data interpretation: Aethalometer scattering correction and Mie theory calculation}

\subsubsection{Aethalometer scattering correction}

As the MAAP corrects for scattering, absorption ( $\left.b_{\text {ap_MAAP }}\right)$ was determined directly from the instrument's reported $\mathrm{BC}$ concentration using the fixed mass absorption coefficient of $6.6 \mathrm{~m}^{2} \mathrm{~g}^{-1}$ at $670 \mathrm{~nm}$ (see acronyms listed in Appendix A). The Aethalometer $b_{\text {ap }}\left(b_{\text {ap_Aeth }}\right)$ was corrected for multiple scattering based on the combination of two correction schemes: Weingartner et al. (2003) and Jung et al. (2010) by

$$
\begin{aligned}
& b_{\text {ap }}=\frac{B_{\text {atn }}}{C \times R_{\text {atn }}} \\
& R_{\text {atn }}=\left(\frac{1}{f}-1\right) \times \frac{\ln (\mathrm{ATN})-\ln (10 \%)}{\ln (50 \%)-\ln (10 \%)}+1 \\
& f=a(1-w 0)+1 \\
& C=4.05 \times\left(\frac{[\mathrm{BC}]}{[\mathrm{EC}]}\right)-1.55,
\end{aligned}
$$

where $B_{\text {atn }}$ is directly derived from the $\mathrm{BC}$ concentration reported by the instrument by $B_{\text {atn }}=B C \times \frac{14625}{\lambda}$ (unit: $\mathrm{BC}$ in $\mathrm{ng} \mathrm{m}^{-3}, B_{\text {atn }}$ in $^{-1}$ ), $R_{\text {atn }}$ (unitless) is a calculated parameter based on Eq. (2), $f$ is an empirical factor that depends on parameter $a$, which is equal to 0.87 at $660 \mathrm{~nm}$, and estimated single scattering albedo, $w 0$, the ratio of scattering to scattering plus absorption. As there was no direct measurement of scattering on-site during the MOUDI sampling periods, scattering was inferred from TEOM $\mathrm{PM}_{2.5}$ data. The linear regression slope of scattering (at $530 \mathrm{~nm}$ ) and TEOM $\mathrm{PM}_{2.5}$ reported in Carrico et al. (2003) was applied to our TEOM data to estimate scattering, then a scattering Ångström exponent of 1.4 (Yang et al., 2009) was used to estimate the scattering at $670 \mathrm{~nm}$ and the single scattering albedo. The estimated single scattering albedo ranged from $0.85-0.91$. The correction factor $\mathrm{C}$ depends on the aerosol type and was determined from the hourly measured $\mathrm{EC}$ and online $\mathrm{BC}$ averaged over the EC sampling time. Aethalometer $b_{\text {ap }}$ uncertainty, including scattering correction, is estimated to be $36 \%$ due to uncertainty in a range of parameters, including measurements of BC, EC, TEOM $\mathrm{PM}_{2.5}$, and related uncertainties associated with the scattering estimation. The magnitude of the scattering correction factor was $3.75 \pm 0.83$ (mean \pm standard deviation).

For comparison, $b_{\text {ap_Aeth }}$ at $660 \mathrm{~nm}$ was converted to the MAAP operational wavelength of $670 \mathrm{~nm}$ based on an absorption Ångström exponent determined from the Aethalometer multiple wavelength measurements (i.e., power law regression fit). For the JST measurements, when both MAAP and Aethalometer data were available, the scattering-corrected $b_{\text {ap_Aeth }}$ agreed with $b_{\text {ap_MAAP }}$ (Fig. 1 , regression slope of $1.02, r^{2}=0.95$ ), indicating the scattering correction at $670 \mathrm{~nm}$ is reasonable.

\subsubsection{Mie theory calculations}

An absorption measurement of solutions containing aerosol extracts is not directly comparable with absorption by ambient aerosols. However, the complex part of refractive indices can be obtained from the solution light-absorption data and used with Mie theory to infer the brown carbon absorption by ambient aerosols, under a range of assumptions.

Spectrophotometric measurements of the solution light absorbance at a given wavelength $\left(A_{\lambda}\right.$, unitless) can be used to determine the bulk solution mass absorption efficiency $(\alpha / \rho)$ by

$$
\frac{\alpha(\lambda)}{\rho}=\frac{\left(A_{\lambda}-A_{700}\right)}{M} \cdot \frac{V_{1}}{V_{\mathrm{a}} \cdot l} \cdot \ln (10)=\frac{\operatorname{Abs}(\lambda)}{M} .
$$

Measurements at wavelengths below $700 \mathrm{~nm}$ are referenced to absorbance at $700 \mathrm{~nm}\left(A_{\lambda}-A_{700}\right)$ to account for any uniform signal drift that may occur over time after LWCC cleaning and zeroing to reference (DI) spectra (only necessary for the online system since offline system was cleaned and zeroed between each measurement). $V_{1}$ is the liquid volume 


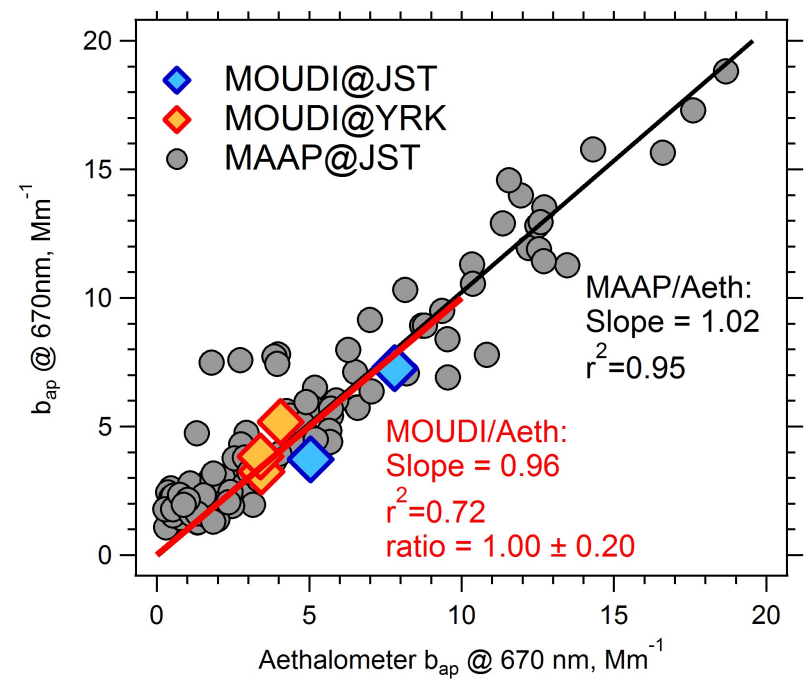

Fig. 1. Comparison of absorption at $670 \mathrm{~nm}$ between scatteringcorrected Aethalometer and MAAP for $1 \mathrm{~h}$ averaged data (grey filled circles) and Aethalometer absorption averaged over MOUDI sampling times to absorption determined from the EC size distribution and Mie theory (diamonds). An orthogonal distance regression (ODR) fit was applied.

the filter is extracted into and $V_{\mathrm{a}}$ the volume of air sampled through the filter. The waveguide optical path length is $l$ and $\ln (10)$ converts from base 10 (the form provided by the spectrophotometer) to natural logarithms. $\operatorname{Abs}(\lambda)$ is then the solution absorption at a given wavelength (units $\mathrm{Mm}^{-1}$ ). $M$ is the mass concentration used to determine the bulk solution mass absorption efficiency $\left(\operatorname{Abs}(\lambda) / M\right.$ in units of $\left.\mathrm{m}^{2} \mathrm{~g}^{-1}\right)$. In this work $M$ is taken to be the ambient WSOC concentration for the water extract and ambient $\mathrm{OC}$ concentration for the methanol extract. The complex component $(k)$ of the particle refractive index $m=n+i k$ can then be calculated from Eq. (5) (Bohren and Hoffman, 1998; Chen and Bond, 2010; Sun et al., 2007) for the water and methanol extracts by

$k=\frac{\rho \lambda\left(\frac{\alpha(\lambda)}{\rho}\right)}{4 \pi}=\frac{\rho \lambda \cdot \mathrm{H}_{2} \mathrm{O} \_\mathrm{Abs}(\lambda)}{4 \pi \cdot \mathrm{WSOC}}$

for water extracts

$k=\frac{\rho \lambda\left(\frac{\alpha(\lambda)}{\rho}\right)}{4 \pi}=\frac{\rho \lambda \cdot \mathrm{MeOH} \_\mathrm{Abs}(\lambda)}{4 \pi \cdot \mathrm{OC}}$

for methanol extracts,

where $\mathrm{H}_{2} \mathrm{O} \_\mathrm{Abs}(\lambda)$ and $\mathrm{MeOH} \_\mathrm{Abs}(\lambda)$ are the solution absorption at a given wavelength for the water and methanol extracts (i.e., $\operatorname{Abs}(\lambda)$ for specific solvents), and WSOC and OC are measured organic carbon mass from ambient collected filters. Note that using a mass $(M)$ of WSOC or OC $\left(\mu \mathrm{gC} \mathrm{m}^{-3}\right)$ results in reported $k$ values for organic carbon mass, not particle mass, and in subsequent Mie calculations of brown carbon absorption, these same mass concentrations must be used for consistency. Alternatively, one could use the total particle mass (PM) measured on each stage (not measured in this study). Since PM/WSOC and PM/OC mass fractions $\left(\mu \mathrm{gCug}^{-1}\right)$ likely range from roughly 2 to $4, k$ would decrease by similar factors if PM were used instead. Sensitivity tests show that there is at most a $20 \%$ difference in Mie-predicted carbon absorption if PM is used instead of carbon mass. In this study, a particle density $(\rho)$ of $1.5 \mathrm{~g} \mathrm{~cm}^{-3}$ for both water and methanol extracts for all particle sizes is assumed. Mie calculated $b_{\text {ap }}$ is largely insensitive to the value chosen; sensitivity tests with our data show a $10 \%$ difference in density results in $\sim 6 \%$ change in $b_{\text {ap }}$ for EC or brown carbon (methanol or water) calculations. Particle density is also used to convert aerodynamic diameters to physical particle diameters needed in the Mie calculation, assuming spherical particles. This added uncertainty is discussed below. For all data collected, the real part of the refractive index $(m)$ was set to 1.55 for all wavelengths, representative of the organicsulfate mix that comprises fine particles in the study region (Carrico et al., 2003). An uncertainty analysis shows that the relative change in estimated $b_{\text {ap }}$ due to $m$ (ranging from 1.4 to 2.0 ) is within $18 \%$.

For each MOUDI stage (and after filter), and for each extract solution, the refractive index was determined and used in a Mie theory calculation to estimate the single particle absorption efficiency $(Q)$ for a particle of size $D_{\mathrm{p}_{\mathrm{g}}}$, the geometric mean of physical diameter for that stage. The lightabsorption coefficient for all particles of that size is then estimated by

$b_{\text {ap }}\left(\lambda, D_{\mathrm{pg}_{\mathrm{g}}}\right)=\frac{\pi}{4} \cdot D_{\mathrm{pg}}^{2} \cdot Q \cdot N$,

where $N$ is the particle number concentration. Since $N$ is not known, the mass concentration, $M$ for the given MOUDI stage, is used to estimate $N$, assuming spherical particles, which gives

$b_{\mathrm{ap}}\left(\lambda, D_{\mathrm{pg}}\right)=\frac{3}{2} \cdot \frac{Q \cdot M}{D_{\mathrm{pg}} \cdot \rho}$.

For consistency with the calculated complex refractive in$\operatorname{dex}(k), M$ is either the WSOC or OC ambient concentration determined from the MOUDI measurement. The calculation is repeated for all stages with cut sizes $3.1 \mu \mathrm{m}$ and below, including the after filter, and then summed to obtain the total fine particle light-absorption coefficient at a given wavelength. The process is repeated for other wavelengths of interest.

This analysis makes a number of simplifying assumptions, including that the particles are spherical and of uniform composition, but externally mixed with other absorbing aerosol components (e.g., EC). As a test of the method, Mie calculations, under similar assumptions, are also made to estimate the absorption by pure $\mathrm{BC}$ at $670 \mathrm{~nm}$ based on MOUDI sizeresolved EC measurements and are compared to Aethalometer and MAAP measurements of $\mathrm{BC} b_{\text {ap }}$ for the JST data. 

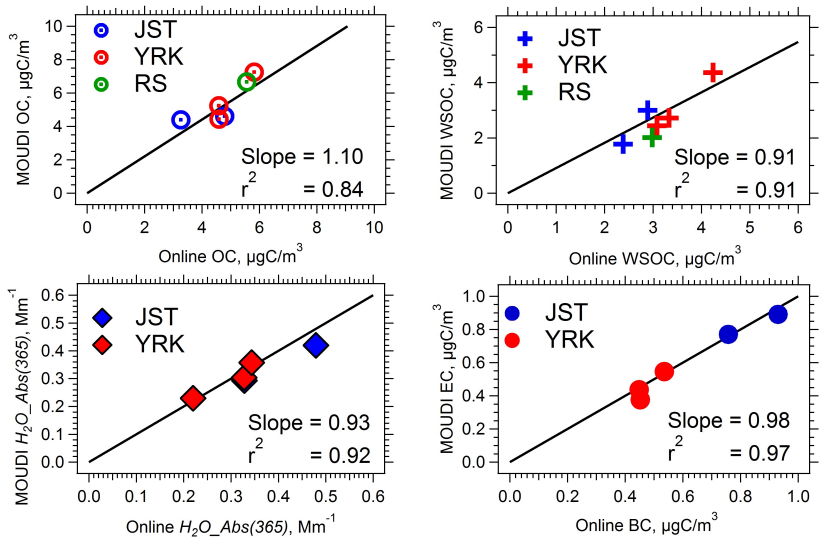

Fig. 2. Comparison of offline fine particle MOUDI OC, EC, WSOC, water-extracted absorption at $365 \mathrm{~nm}$ and online $\mathrm{OC}, \mathrm{BC}$, WSOC, and water-soluble absorption at $365 \mathrm{~nm}$ using orthogonal distance regressions with slopes forced through zero. Online data are $\mathrm{PM}_{2.5}$ and MOUDI summed over all stages of $3.1 \mu \mathrm{m}$ cut and below (plus after filter). The sites are JST (urban), YRK (rural) and RS (roadside). No online $\mathrm{H}_{2} \mathrm{O}_{\mathrm{Abs}}$ or $\mathrm{BC}$ was available at the $\mathrm{RS}$ site during the MOUDI sampling period.

Aethalometer-measured absorption at lower wavelengths is then compared to water and methanol brown carbon $b_{\text {ap }}$ derived from a similar Mie calculation.

\section{Results}

\subsection{MOUDI vs. online data; data quality assessment}

Off-line MOUDI data were integrated over stages of aerodynamic cut size $3.1 \mu \mathrm{m}$ and smaller (including the after filter) and compared to the $\mathrm{PM}_{2.5}$ online measurements, averaged over MOUDI sampling times. Comparisons for WSOC, OC, EC, and $\mathrm{H}_{2} \mathrm{O} \_A b s(365)$ (i.e., at a wavelength of $365 \mathrm{~nm}$ ) are shown in Fig. 2. (Note, only water extracts were available for the online method, so no comparison of $\mathrm{MeOH} \_\mathrm{Abs}(365)$ is available). There is good agreement between the online and offline methods. For all four components the correlations $\left(r^{2}\right)$ were greater than 0.84 and slopes within $10 \%$ of one, well within the instrumental measurement uncertainties of roughly 10 to $30 \%$ (Table 2 ).

\subsection{MOUDI size distributions}

A summary of MOUDI sampling dates and times, and average conditions measured with the various instruments during these periods is given in Table 1. Although measurements were not made simultaneously at the different sites, the comparisons between sites show differences (or lack there of) expected for primary and secondary aerosol components. For example, both EC and OC concentrations were highest at the RS site, compared to JST and YRK, which tended to be closer in magnitude. WSOC concentrations were similar

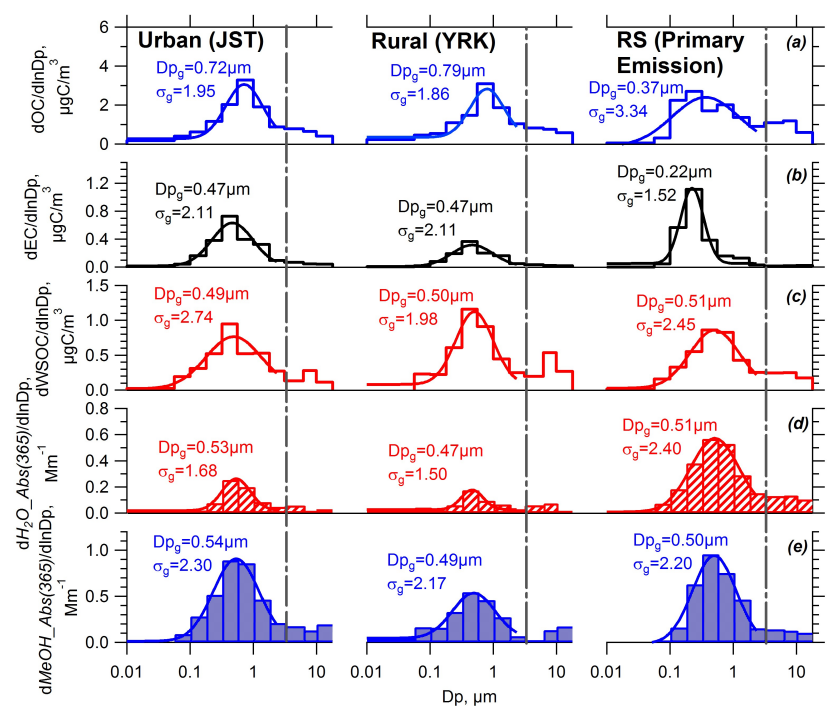

Fig. 3. Size distributions of (a) OC, (b) EC, (c) WSOC, (d) watersoluble absorption $(365 \mathrm{~nm})$, and (e) methanol-soluble absorption $(365 \mathrm{~nm})$ from MOUDI samples collected at JST, YRK and RS sites. The after filter is included as a size channel from 0.01 to $0.056 \mu \mathrm{m}$. The vertical line at $3.1 \mu \mathrm{m}$ and all measurements below that size are viewed as fine particles. For JST and YRK the multiple measurements have been averaged. Geometric mean diameters and geometric standard deviations from lognormal fits to fine particles are included. Particle sizes are aerodynamic diameters.

among all three sites. OC/EC ratios were highest at the rural site and lowest at the RS site. These results are consistent with known high spatial variability in primary species, $\mathrm{EC}$ and some fraction of $\mathrm{OC}$, and more uniformity in secondary species (e.g., WSOC) and high OC/EC ratios in regions dominated by secondary organic aerosols.

MOUDI size distributions for the individual species, including extract solutions of water-soluble $\left(\mathrm{H}_{2} \mathrm{O} \_\mathrm{Abs}(365)\right)$ and methanol-soluble absorption at $365 \mathrm{~nm}$ (MeOH_Abs(365)) at the three sites are shown in Fig. 3. Geometric mean aerodynamic diameters and standard deviations, based on lognormal fits to the data over fine particle ranges (i.e., MOUDI stages with cut sizes $3.1 \mu \mathrm{m}$ and below), are included in the plots.

Like the online data, the size distributions of EC and OC were generally consistent among the five sets of samples collected at JST and YRK, but differed from the RS sample. RS OC and EC were significantly shifted to lower size ranges, similar to previous observations which show that fresh vehicular emissions are associated with smaller sizes. Aged carbonaceous particles (both OC and EC) tend to be larger due to accretion of mass, with typical urban carbonaceous aerosols often peaking at size ranges of $0.56-1.0 \mu \mathrm{m}$ (Chow et al., 2008; Huang et al., 2006; Lan et al., 2011). In contrast, measurements of WSOC and brown carbon (both water and methanol extracts) had similar distributions among all three sites, including RS, with geometric mean diameters all near 
$0.5 \mu \mathrm{m}$. Light absorption for the water and methanol extracts at other wavelengths $\left(\mathrm{H}_{2} \mathrm{O} \_\mathrm{Abs}(\lambda)\right.$ and $\left.\mathrm{MeOH} \_\mathrm{Abs}(\lambda)\right)$ had similar size distributions as those plotted and all were very similar to those of WSOC.

\subsubsection{Water and methanol extract spectrophotometric results}

Before calculating the light absorption due to the chromophores, the bulk solution properties for both water and methanol extractions are first discussed. Figure 4 shows typical spectra of water and methanol extracts from the same sample (JST MOUDI stage 6, aerodynamic diameter between 0.56 and $1.00 \mu \mathrm{m}$ ). Although the complete lightabsorption spectra were recorded from 200 to $800 \mathrm{~nm}$, signals below $300 \mathrm{~nm}$ and larger than $700 \mathrm{~nm}$ have a substantial amount of noise and therefore were not included in the analysis of optical properties. The absorption spectra are consistent in shape with other studies (e.g., Duarte et al., 2005; Sun et al., 2007; Hecobian et al., 2010; Chen and Bond, 2010; Zhang et al., 2013) of brown carbon and have the common characteristic of increasing absorbance with decreasing wavelength, with little to no absorption above mid-visible. These spectra are in stark contrast to black carbon absorption, with absorption Ångström exponents close to 1 (discussed further below) and confirm that light absorption is due to a different aerosol component (i.e., brown carbon). Table 3 compares light absorption in water and methanol extracts over fine particle sizes for all three sites (data averaged at each site) at different wavelengths. Comparisons from the table show a number of interesting features.

1. Light absorption by organic carbon extracted in water is always smaller than methanol extracts, although the value varies with wavelength and site. This is expected since methanol should extract a greater range of compounds than just the polar compounds dissolved by the water extraction process, as has been seen in other studies (Chen and Bond, 2010; Zhang et al., 2013).

2. Although absorption drops off with increasing wavelength, $\mathrm{MeOH} \_\mathrm{Abs}(\lambda)$ decreased more slowly and so absorbs more at higher wavelengths than water extracts (water/methanol ratio is much smaller at $571 \mathrm{~nm}$ compared to lower wavelengths). This is similar to the findings of Zhang et al. (2013) and thought to be due to higher molecular weight chromophores exclusive to the methanol extract that absorb at higher wavelengths.

3. Mass absorption efficiencies $(\alpha / \rho)$ are higher at the RS site indicating the role of primary vehicle emissions as a brown carbon source (Hecobian et al., 2010; Zhang et al., 2011).

4. Surprisingly, fresher emissions at the RS site have a greater fraction of water-soluble chromophores com-
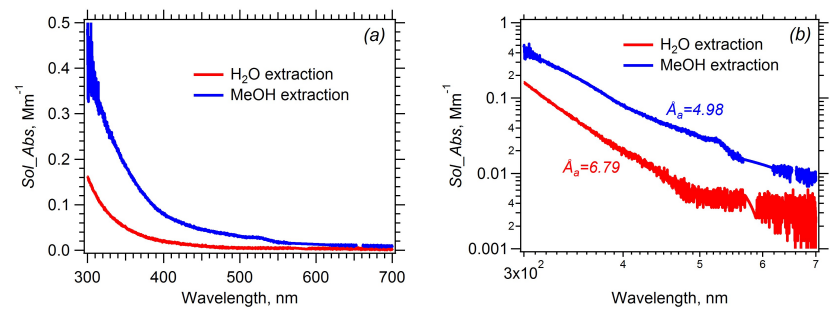

Fig. 4. Example solution spectra of $\mathrm{H}_{2} \mathrm{O}$ and $\mathrm{MeOH}$ (methanol) extracts from the same MOUDI stage (JST, 25-27 May 2012, stage 6 with particle aerodynamic diameter between 0.56 and $1.0 \mu \mathrm{m}$ ). Absorption Ångström exponent is calculated by linear regression fit to $\log A b s$ vs. $\log \lambda$ in the wavelength range of $300-500 \mathrm{~nm}$.

pared with the more aged regional JST and YRK samples. For example, water/methanol light-absorption ratios were higher than 0.53 at the RS site, but range between about 0.1 and 0.4 at JST and YRK, and $(\alpha / \rho$ water $) /(\alpha / \rho$ methanol $)$ ratios were greater than 1.5 at RS, but less than 0.6 for JST and YRK. This may suggest that the chromophores become less water soluble with age, possibly due to chemical aging. However, because measurements at various sites were not made simultaneously, these contrasts are somewhat uncertain.

\subsection{Light absorption from Mie calculations}

\subsubsection{Comparison of predicted $\mathrm{BC}$ absorption based on EC size distributions to measured $\mathrm{BC}$}

To roughly gauge the validity of the MOUDI size-resolved Mie calculation (with its inherent assumptions) at predicting light absorption by aerosols, Mie theory was first used to estimate $b_{\text {ap }}$ from MOUDI-EC data $\left(b_{\text {ap_EC }}\right)$, which is then compared with the co-located, scattering corrected, $b_{\text {ap }}$ by Aethalometer $\left(b_{\text {ap_Aeth }}\right)$. First, Mie calculations were done at the MAAP wavelength of $670 \mathrm{~nm}$, a wavelength where $b_{\text {ap_Aeth }}$ should not be affected by brown carbon (see Fig. 4 ), and where $b_{\text {ap_Aeth }}$ and $b_{\text {ap_MAAP }}$ are in close agreement.

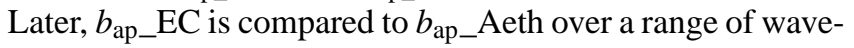
lengths. The Mie calculation is based on the EC concentrations (NIOSH method, thermal EC) measured on each stage, an assumed refractive index of 1.97-0.79i, (Bond and Bergstrom, 2006) and an EC density of $1.8 \mathrm{~g} \mathrm{~cm}^{-3}$ (Bond and Bergstrom, 2006). Light absorption $\left(b_{\mathrm{ap}}\right)$ is calculated for each stage and the sum for the $3.1 \mu \mathrm{m}$ stage and below (plus after filter) is compared to $b_{\text {ap_Aeth, }}$, shown in Fig. 1. Five direct comparisons are possible from the JST and YRK studies (Aethalometer data is not available at the RS site). $b_{\text {ap_EC }}$ is in good agreement with the Aethalometer measurements, with a largest deviation of $27 \%$. The mean \pm std dev of the MOUDI/Aeth $b_{\text {ap }}$ ratio was $1.00 \pm 0.20$. The good agreement between $b_{\text {ap_EC }}$ and light-absorption data from optical instruments is similar to that found by Carrico et al. (2003), 
Table 3. Values of absorption, absorption per mass $\alpha / \rho$ (normalized by WSOC for water extracts and OC for methanol extracts) and the ratio between water and methanol extracts for samples collected at JST (urban), YRK (rural) and RS (road-side). Data are averages for all stages $3.1 \mu \mathrm{m}$ and below, plus the after filter. Unit of absorption (Abs) is $\mathrm{Mm}^{-1}$, and for $\alpha / \rho$ the unit is $\mathrm{m}^{2} \mathrm{~g}^{-1}$ (see Eq. 5).

\begin{tabular}{lcccc|cccc}
\hline & \multicolumn{5}{c}{ Abs (water) } & \multicolumn{4}{c}{$\alpha / \rho$ (water) } \\
\cline { 2 - 9 } & $350 \mathrm{~nm}$ & $365 \mathrm{~nm}$ & $450 \mathrm{~nm}$ & $571 \mathrm{~nm}$ & $350 \mathrm{~nm}$ & $365 \mathrm{~nm}$ & $450 \mathrm{~nm}$ & $571 \mathrm{~nm}$ \\
\hline JST & 0.40 & 0.33 & 0.17 & 0.019 & 0.16 & 0.14 & 0.071 & 0.0078 \\
YRK & 0.46 & 0.32 & 0.18 & 0.019 & 0.19 & 0.13 & 0.072 & 0.0078 \\
RS & 1.75 & 1.27 & 0.24 & 0.04 & 0.73 & 0.53 & 0.10 & 0.016 \\
\hline & \multicolumn{5}{c}{ Abs (methanol) } & & $\alpha / \rho$ (methanol) & \\
\cline { 2 - 9 } & $350 \mathrm{~nm}$ & $365 \mathrm{~nm}$ & $450 \mathrm{~nm}$ & $571 \mathrm{~nm}$ & $350 \mathrm{~nm}$ & $365 \mathrm{~nm}$ & $450 \mathrm{~nm}$ & $571 \mathrm{~nm}$ \\
\hline JST & 0.99 & 1.34 & 0.64 & 0.20 & 0.29 & 0.39 & 0.19 & 0.060 \\
YRK & 1.33 & 1.39 & 0.66 & 0.18 & 0.39 & 0.41 & 0.19 & 0.054 \\
RS & 2.38 & 1.80 & 0.36 & 0.08 & 0.36 & 0.27 & 0.056 & 0.011 \\
\hline & Ratio of absorption (water/methanol) & Ratio of $\alpha / \rho$ (water/methanol) \\
\cline { 2 - 10 } & $350 \mathrm{~nm}$ & $365 \mathrm{~nm}$ & $450 \mathrm{~nm}$ & $571 \mathrm{~nm}$ & $350 \mathrm{~nm}$ & $365 \mathrm{~nm}$ & $450 \mathrm{~nm}$ & $571 \mathrm{~nm}$ \\
JST & 0.40 & 0.24 & 0.27 & 0.09 & 0.56 & 0.34 & 0.38 & 0.13 \\
YRK & 0.35 & 0.23 & 0.26 & 0.10 & 0.49 & 0.32 & 0.38 & 0.15 \\
RS & 0.74 & 0.71 & 0.67 & 0.53 & 2.03 & 1.96 & 1.79 & 1.45 \\
\hline
\end{tabular}

which reported a model/measured ratio of $1.12 \pm 0.36$. The results suggest that it is not necessary to apply more complex internal mixtures and/or core/shell assumptions for particles to accurately estimate the light-absorption coefficient based on size distributions measurements of EC at longer visible wavelengths.

\subsubsection{Uncertainties in Mie-predicted absorption}

The sensitivity of predicted $b_{\text {ap_EC }}$ (and similarly for $b_{\text {ap, } \mathrm{H}_{2} \mathrm{O}}$ and $b_{\mathrm{ap}, \mathrm{MeOH}}$ discussed below) to the various measured and assumed parameters used in the calculation were assessed. Variability in particle density $( \pm 10 \%)$, both directly in the Mie calculation and conversion of aerodynamic to physical diameter, the use of a single particle size for each MOUDI stage, sensitivity to the real part of the refractive index $(m$ range of 1.4 to 2.0), and including variability in using carbon mass for $M$ (discussed above), leads to an overall uncertainty in $b_{\text {ap_EC }}$ (and $b_{\text {ap, } \mathrm{H}_{2} \mathrm{O}}$ and $\left.b_{\mathrm{ap}, \mathrm{MeOH}}\right)$ of $30 \%$, when combined by quadrature sum of squares (see Table 2). Including uncertainty associated with the EC measurement, the $b_{\text {ap_EC }}$ uncertainty is $34 \%$. Thus, differences between online $b_{\text {ap_Aeth }}$ and $b_{\text {ap_EC }}$ of less than $27 \%$ are well within associated uncertainties $\left(b_{\text {ap_Aeth }} \pm 36 \%\right.$ and $\left.b_{\text {ap_EC }} \pm 34 \%\right)$.

\subsubsection{Brown carbon refractive index for Mie calculations}

There is limited data on the complex component $(k)$ of the ambient particle refractive index due to brown carbon. $k$ depends on wavelength, which accounts for the color, and can vary with particle size. Reported values range from 0.002 to
0.27 at wavelengths between roughly $500-550 \mathrm{~nm}$ (Dinar et al., 2008; Hoffer et al., 2006; Lukacs et al., 2007; Kirchstetter et al., 2004). Alexander et al. (2008) reported a $k$ of 0.27 at $550 \mathrm{~nm}$ for aerosols in East Asian-Pacific outflow. Biomass burning HULIS extracted in water had a solution $k$ of 0.0018 at $532 \mathrm{~nm}$ (Hoffer et al., 2006). Lack et al. (2012) reported a $k$ value of 0.009 at $404 \mathrm{~nm}$ for aerosols originated from biomass burning plumes. Given the variety of locations, expected variability in aerosol sources and analytical methods used to determine $k$, wide variability in $k$ may be expected.

Table 4 summarizes values of $k$ determined from the MOUDI samples at the three sites for three wavelengths, and for each MOUDI stage (particle size). As noted, the $k$ values reported here are referenced to organic carbon mass. As expected, wavelength has the largest effect on $k$. Variability in $k$ was fairly small over the various MOUDI stages for water-soluble brown carbon. This is because size distributions for both water-soluble brown carbon absorption and WSOC concentration have a similar shape and so $\alpha / \rho$ does not vary significantly among the MOUDI stages. More variability is seen in $k$ for methanol-extractable brown carbon due to larger differences between $\mathrm{MeOH} \_\mathrm{Abs}(\lambda)$ and $\mathrm{OC}$ distributions. Averaged over all fine particle sizes (average is determined by including a mass concentration weighting), for JST and YRK samples, $k$ is $0.0040 \pm 0.0011$ for water soluble and $0.0082 \pm 0.0036$ for methanol soluble extracts at $350 \mathrm{~nm}$. These values decrease to $0.0002 \pm 0.0001$ and $0.0009 \pm 0.0004$ at $571 \mathrm{~nm}$, assuming the same particle density for both WSOC and OC of $1.5 \mathrm{~g} \mathrm{~cm}^{-3}$ (Carrico et al., 2003). These values are significantly higher at the RS site, 

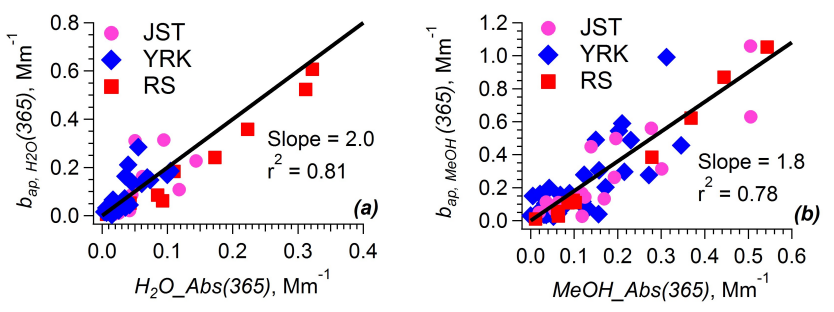

Fig. 5. Comparison of Mie-predicted absorption to solution absorption for (a) water extracts and (b) methanol extracts at $365 \mathrm{~nm}$. Data are all fine stages from the 6 MOUDI samples collected. An orthogonal distance regression (ODR) fit was applied. The correlation did not change with either aerosol size or sampling sites suggesting a robust relationship. The slope and $r^{2}$ given is for combined data.

where there is a larger impact from primary vehicle emissions.

\subsubsection{Water and methanol Mie results: brown carbon $b_{\text {ap }}$ solution vs. Mie-predicted light absorption}

Figure 5 shows the comparisons between the absorption measured in the solutions at $365 \mathrm{~nm}(\mathrm{Abs}(365))$ and Miepredicted brown carbon light absorption by the particles for both water $\left(b_{\mathrm{ap}, \mathrm{H}_{2} \mathrm{O}}\right)$ and methanol $\left(b_{\mathrm{ap}, \mathrm{MeOH}}\right)$ extracts at $365 \mathrm{~nm}$. For both water and methanol extracts, the correlations are high and very similar among all three sampling sites. They also did not change significantly with aerosol size. Mie predicted $b_{\mathrm{ap}, \mathrm{H}_{2} \mathrm{O}}$ and $b_{\mathrm{ap}, \mathrm{MeOH}}$ were factors of 2 and 1.8, respectively, times the bulk solution measurement (i.e., $b_{\text {ap, } \mathrm{H}_{2} \mathrm{O}} / \mathrm{H}_{2} \mathrm{O} \_$Abs and $b_{\text {ap, }} \mathrm{MeOH} / \mathrm{MeOH} \_\mathrm{Abs}$, at $365 \mathrm{~nm}$ ). For higher wavelengths, the ratios were similar (e.g., 1.9 and 1.8, respectively, at $450 \mathrm{~nm}$ ). Previous studies generally assume a small particle limit, where the particle size is not comparable to wavelength, when estimating particle light absorption from bulk solutions, in which case the factor is 0.69 to 0.75 (Nakayama et al., 2013; Sun et al., 2007). In contrast, our results suggest that because the ambient brown carbon aerosols are in the accumulation mode, the actual atmospheric absorption is approximately 2 times higher than what is estimated by bulk absorption in liquids and that this is a fairly robust conversion factor.

\subsubsection{Comparison of brown carbon absorption to black carbon}

Comparisons between calculated brown carbon absorption ( $b_{\mathrm{ap}, \mathrm{H}_{2} \mathrm{O}}$ and $\left.b_{\mathrm{ap}, \mathrm{MeOH}}\right)$ to that of EC absorption predicted by the Mie calculation ( $b_{\text {ap_EC }}$ ) and $\mathrm{BC}$ absorption measured by the Aethalometer $\left(b_{\text {ap_Aeth }}\right)$, for all three sites, are shown in Fig. 6a. The Mie calculations were made at the various Aethalometer measurement wavelengths. In each case, the $b_{\text {ap }}$ data are fitted with a power law to provide the absorption Ångström exponents. Representative uncertainties are
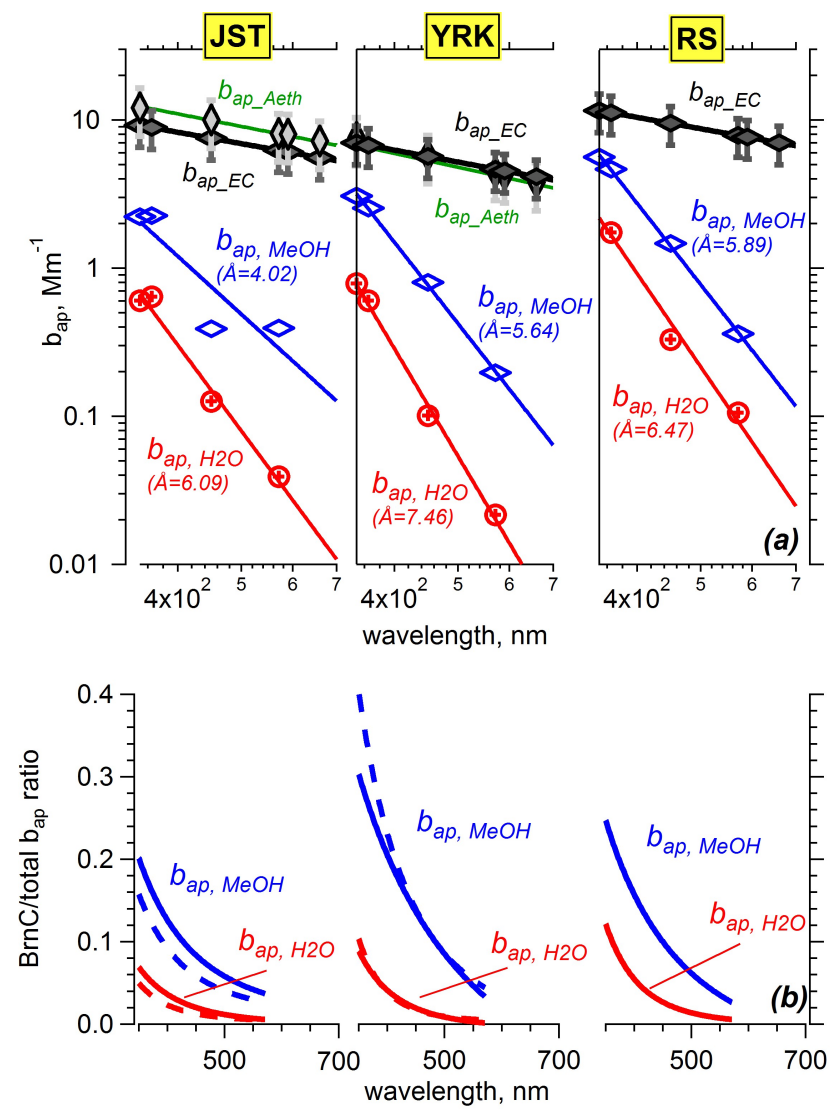

Fig. 6. (a) Mie-predicted absorption of methaol-soluble brown carbon, water-soluble brown carbon, and $\mathrm{BC}$ absorption from EC data, and Aethalometer-measured BC absorption, all at the 7 wavelengths of the Aethalometer. (b) contribution of brown carbon (water soluble and methanol soluble) to total light absorption at JST, YRK and RS sites, where solid lines show the relative fraction to EC plus BrnC (e.g., $b_{\text {ap, } \mathrm{MeOH}} /\left(b_{\text {ap }, \mathrm{MeOH}}+b_{\text {ap_EC }}\right)$, or $\left.b_{\text {ap, } \mathrm{H}_{2} \mathrm{O}} /\left(b_{\text {ap }, \mathrm{H}_{2} \mathrm{O}}+b_{\text {ap_EC }}\right)\right)$, and dotted lines show the fraction relative to Aethalometer absorption (e.g., $b_{\text {ap }, \mathrm{MeOH}} / b_{\text {ap_Aeth }}$ or $\left.b_{\text {ap }, \mathrm{H}_{2} \mathrm{O}} / b_{\text {ap_Aeth }}\right)$. No Aethalometer data were available at the RS site. For JST and YRK, where multiple MOUDI measurements were made, averages are plotted. Error bars are based on calculations summarized in Table 2, where additional estimates of errors can be found.

included in the plot and summarized in Table 2. Data for Fig. 6a are provided in Table 5.

From Fig. $6 \mathrm{a}$ it is noted that differences in $b_{\text {ap_EC }}$ between sites for the various $\lambda$ is similar to what was discussed above for the EC concentrations. As a rural site, YRK $b_{\text {ap_EC }}$ is somewhat lower compared to JST, and both were significantly lower than the RS site, which was almost twice the YRK level. Similar differences are seen for Brown carbon $\left(b_{\mathrm{ap}, \mathrm{H}_{2} \mathrm{O}}\right.$ and $\left.b_{\mathrm{ap}, \mathrm{MeOH}}\right)$, with highest absorption for the various $\lambda$ at the RS site, and more similar levels at JST and YRK. Curiously, $b_{\mathrm{ap}, \mathrm{H}_{2} \mathrm{O}}$ and $b_{\mathrm{ap}, \mathrm{MeOH}}$ at $\mathrm{YRK}$ were slightly higher than JST, although $b_{\text {ap_EC }}$ was lower, suggesting a brown carbon source in the rural region. 
Table 4. Derived absorbing component of the complex refractive index $(k)$ of brown carbon from MOUDI substrates extracted in water or methanol $\left(\mathrm{H}_{2} \mathrm{O} \_\mathrm{Abs}(\lambda)\right.$ or $\left.\mathrm{MeOH} \_\mathrm{Abs}(\lambda)\right)$. Tabulated values are $k \times 10^{3}$. Note that these refractive indices are assuming externally mixed aerosols composed of only WSOC or OC, i.e., they are calculated using WSOC and OC mass, see Eqs. (6) and (7).

\begin{tabular}{|c|c|c|c|c|c|c|c|c|c|c|c|c|c|c|c|c|c|c|}
\hline \multirow{3}{*}{$\mathrm{Dp}_{50}, \mu \mathrm{m}$} & \multicolumn{6}{|c|}{ JST } & \multicolumn{6}{|c|}{ YRK } & \multicolumn{6}{|c|}{ RS } \\
\hline & \multicolumn{2}{|c|}{$350 \mathrm{~nm}$} & \multicolumn{2}{|c|}{$450 \mathrm{~nm}$} & \multicolumn{2}{|c|}{$571 \mathrm{~nm}$} & \multicolumn{2}{|c|}{$350 \mathrm{~nm}$} & \multicolumn{2}{|c|}{$450 \mathrm{~nm}$} & \multicolumn{2}{|c|}{$571 \mathrm{~nm}$} & \multicolumn{2}{|c|}{$350 \mathrm{~nm}$} & \multicolumn{2}{|c|}{$450 \mathrm{~nm}$} & \multicolumn{2}{|c|}{$571 \mathrm{~nm}$} \\
\hline & $\mathrm{H}_{2} \mathrm{O}$ & $\mathrm{MeOH}$ & $\mathrm{H}_{2} \mathrm{O}$ & $\mathrm{MeOH}$ & $\mathrm{H}_{2} \mathrm{O}$ & $\mathrm{MeOH}$ & $\mathrm{H}_{2} \mathrm{O}$ & $\mathrm{MeOH}$ & $\mathrm{H}_{2} \mathrm{O}$ & $\mathrm{MeOH}$ & $\mathrm{H}_{2} \mathrm{O}$ & $\mathrm{MeOH}$ & $\mathrm{H}_{2} \mathrm{O}$ & $\mathrm{MeOH}$ & $\mathrm{H}_{2} \mathrm{O}$ & $\mathrm{MeOH}$ & $\mathrm{H}_{2} \mathrm{O}$ & $\mathrm{MeOH}$ \\
\hline 2.36 & 3.14 & 4.64 & 0.39 & 2.76 & $\sim 0$ & 0.78 & 2.58 & 3.23 & 0.90 & 0.83 & 0.29 & 0.21 & 13.58 & 3.79 & 1.96 & 0.67 & 0.31 & 0.12 \\
\hline 1.34 & 2.66 & 4.91 & 0.69 & 2.62 & 0.38 & 0.49 & 2.55 & 6.71 & 0.93 & 1.89 & 0.16 & 0.51 & 14.93 & 7.58 & 2.16 & 1.34 & 0.34 & 0.25 \\
\hline 0.75 & 5.16 & 5.32 & 1.12 & 3.20 & 0.22 & 1.13 & 4.67 & 7.30 & 1.16 & 2.18 & 0.16 & 0.64 & 14.03 & 8.36 & 2.03 & 1.48 & 0.32 & 0.27 \\
\hline 0.42 & 4.36 & 10.38 & 1.74 & 4.55 & 0.10 & 1.46 & 5.71 & 14.54 & 1.26 & 4.66 & 0.18 & 1.47 & 14.70 & 12.48 & 2.12 & 2.20 & 0.34 & 0.41 \\
\hline 0.24 & 3.67 & 8.91 & 0.90 & 4.25 & 0.26 & 1.54 & 3.52 & 11.95 & 0.91 & 3.64 & 0.12 & 1.00 & 15.37 & 8.05 & 2.22 & 1.42 & 0.35 & 0.26 \\
\hline 0.13 & 3.23 & 7.23 & 0.58 & 2.88 & 0.30 & 0.99 & 4.59 & 10.94 & 0.87 & 3.66 & 0.28 & 1.09 & 12.48 & 1.63 & 1.80 & 0.29 & 0.29 & 0.05 \\
\hline 0.07 & 3.57 & 3.41 & 1.75 & 2.56 & 0.31 & 0.55 & 5.79 & 14.12 & 0.45 & 4.46 & 0.33 & 1.16 & 10.03 & 1.33 & 1.45 & 0.23 & 0.23 & 0.04 \\
\hline
\end{tabular}

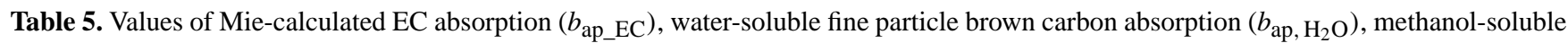
fine particle brown carbon absorption $\left(b_{\mathrm{ap}, \mathrm{MeOH}}\right)$, and scattering corrected Aethalometer absorption $\left(b_{\mathrm{ap}}\right.$ _Aeth $)$ for various wavelengths at all three sites. Units are $\mathrm{Mm}^{-1}$. Data are averages for cases of multiple MOUDI measurements at a given site and are also plotted in Fig. 6.

\begin{tabular}{|c|c|c|c|c|c|c|c|c|c|c|c|}
\hline \multirow{2}{*}{$\begin{array}{l}\text { Wagelength, } \\
\qquad \mathrm{nm}\end{array}$} & \multicolumn{4}{|c|}{ JST } & \multicolumn{4}{|c|}{ YRK } & \multicolumn{3}{|c|}{$\mathrm{RS}$} \\
\hline & $b_{\text {ap_Aeth }}$ & $b_{\text {ap_EC }}$ & $b_{\mathrm{ap}, \mathrm{H}_{2} \mathrm{O}}$ & $b_{\mathrm{ap}, \mathrm{MeOH}}$ & $b_{\text {ap_Aeth }}$ & $b_{\text {ap_EC }}$ & $b_{\text {ap }, \mathrm{H}_{2} \mathrm{O}}$ & $b_{\mathrm{ap}, \mathrm{MeOH}}$ & $b_{\text {ap_EC }}$ & $b_{\text {ap, } \mathrm{H}_{2} \mathrm{O}}$ & $b_{\mathrm{ap}, \mathrm{MeOH}}$ \\
\hline 350 & 12.11 & 9.18 & 0.60 & 2.22 & 7.62 & 6.99 & 0.79 & 3.07 & 11.57 & NAN & 5.62 \\
\hline 365 & NAN & 8.88 & 0.64 & 2.26 & NAN & 6.76 & 0.60 & 2.54 & 11.20 & 1.74 & 4.65 \\
\hline 450 & 9.97 & 7.53 & 0.13 & 0.39 & 5.78 & 5.68 & 0.10 & 0.80 & 9.49 & 0.33 & 1.47 \\
\hline 571 & 8.08 & 6.24 & 0.04 & 0.39 & 4.45 & 4.66 & 0.02 & 0.20 & 7.86 & 0.11 & 0.36 \\
\hline 590 & 8.03 & 6.08 & BDL & BDL & 4.29 & 4.53 & BDL & BDL & 7.66 & BDL & BDL \\
\hline 660 & 7.20 & 5.56 & BDL & BDL & 3.79 & 4.13 & BDL & BDL & 7.01 & BDL & BDL \\
\hline
\end{tabular}

Comparing Mie-predicted EC absorption to the Aethalometer measurement shows that when multiple measurements at a given site were averaged, $b_{\text {ap_EC }}$ was systematically lower than $b_{\text {ap_Aeth }}$ by $\sim 30 \%$ at JST for all wavelengths, but the two were similar at YRK, over the 300-700 nm wavelength ranges (also see Table 5). This can also been seen in the comparison at $670 \mathrm{~nm}$ shown in Fig. 1 . The cause of this is unknown. Bond and Bergstrom (2006) have suggested that Mie theory leads to an under-prediction of the mass absorption efficiency for EC due to interactions between the spherules that form the aggregate, but no such discrepancy is seen at YRK.

Absorption Ångström exponents for the Aethalometer data were $0.95 \pm 0.02$ and $0.91 \pm 0.03$ for JST and YRK (no Aethalometer data available at RS), respectively, ( \pm is $1 \sigma$ regression uncertainty), and $b_{\mathrm{ap}}$, EC had similar values. These exponents are consistent with that of pure black carbon, where a value of $\sim 1$ is typical (Kirchstetter et al., 2004). In contrast, the brown carbon had significantly higher absorption Ångström exponents, ranging from 4 to 6 for $b_{\mathrm{ap}, \mathrm{MeOH}}$

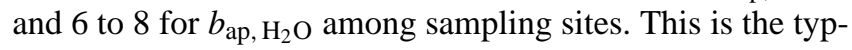
ical spectral characteristic of brown carbon of increasing absorption with lower wavelength, and with little absorption at wavelengths greater than roughly $550 \mathrm{~nm}$. Note that these absorption Angström exponents from the Mie-predicted brown carbon absorption by particles $\left(b_{\mathrm{ap}}\right)$ are similar to those of the bulk solution (Fig. 4 and see Zhang, et al., 2013, and ref- erences therein) suggesting bulk solutions can reasonably be used to directly estimate particle absorption Ångström exponents.

Figure $6 \mathrm{~b}$ shows the magnitude of $b_{\text {ap, } \mathrm{MeOH}}$ and $b_{\text {ap, } \mathrm{H}_{2} \mathrm{O}}$ at different wavelengths relative to total absorption, with total ambient particle absorption estimated in two ways; (1) from the sum of $b_{\text {ap_EC }}$ plus water or methanol brown carbon (solid line), and (2) relative to just the Aethalometer data ( $b_{\text {ap_Aeth }}$, dotted line). The two estimates differed by typically less than $10 \%$. These results suggest the contribution of brown carbon is approximately $5-10 \%$ relative to total absorption for water soluble, and 20-40\% for methanol-soluble components at $350 \mathrm{~nm}$. At larger wavelengths the fraction drops rapidly, reaching approximately zero near $550 \mathrm{~nm}$.

Comparing these fractional contributions of brown carbon among the three sites it is seen that although levels of brown carbon at the RS were largest, due to primary emissions (EC and $\mathrm{BC}$ was also elevated), the fraction of brown to total light absorption was not correspondingly higher relative to the other sites. The highest fraction of brown carbon was at YRK, due to relatively high WSOC and OC concentrations with significantly lower EC concentrations (e.g., highest OC/EC ratios, see Table 2). The results suggest that from a relative point of view (but not in terms of absolute absorption), the role of brown carbon may be most important in regions not associated with strong EC sources, such as remote locations. Possible contributions from natural 
Table 6. Comparison of estimated brown carbon contribution in the present study with previous reports.

\begin{tabular}{|c|c|c|c|c|c|}
\hline $\begin{array}{l}\text { Wavelength } \\
(\mathrm{nm})\end{array}$ & $\begin{array}{r}\text { brnC } \\
\text { fraction }\end{array}$ & $\begin{array}{r}b_{\mathrm{ap}} \\
\left(\mathrm{Mm}^{-1}\right)\end{array}$ & Location & $\begin{array}{l}\text { Instrumentation/ } \\
\text { method }\end{array}$ & Reference \\
\hline 300 & Up to $50 \%$ & - & Rond`onia, Brazil & $\begin{array}{l}\text { PAS and } \\
\text { Nephelometer+Mie }\end{array}$ & Hoffer et al. (2006) \\
\hline 400 & $\sim 40 \%$ & $\sim 200$ & Mexico City & $\begin{array}{l}\text { Multi-Filter Rotating } \\
\text { Shadowband Radiometer }\end{array}$ & Barnard et al. (2008) \\
\hline 400 & $\sim 30 \%$ & $\sim 80$ & Xianghe, China & $\begin{array}{l}\text { PSAP, Aethalometer and } \\
\text { Nephelometer }\end{array}$ & Yang et al. (2009) \\
\hline 550 & $\sim 10 \%$ & $\sim 50$ & Xianghe, China & & Yang et al. (2009) \\
\hline 440 & $\sim 40 \%$ & - & $\mathrm{CA}$ & AERONET dataset & Bahadur et al. (2012) \\
\hline 405 & $13 \%$ & - & Los Angeles region, CA & $\begin{array}{l}\text { Photoacoustic- } \\
\text { spectroscopy }\end{array}$ & Cappa et al. (2012) \\
\hline 532 & $6 \%$ & - & Los Angeles region, CA & & Cappa et al. (2012) \\
\hline 400 & 10 to $30 \%$ & $10-15$ & YRK, JST, RS & $\begin{array}{l}\text { Spectrophotometer } \\
\text { measurements of liquid }\end{array}$ & This study, Methanol \\
\hline 500 & 5 to $10 \%$ & $8-12$ & YRK, JST, RS & extracts + Mie calculations & This study, Methanol \\
\hline
\end{tabular}

(biogenic) sources, or generation of secondary brown carbon due to chemical aging, may account for the higher proportion of brown to black carbon. It is noted that this study was not significantly impacted by biomass burning emissions, which are a known strong source for brown carbon.

\subsubsection{Comparisons to other studies}

The results of this direct measurement of brown carbon combined with a simple Mie calculation shows significant absorption at UV wavelengths relative to BC. Similar results have been reported from both observations and model simulations using a variety of methods to infer brown carbon $b_{\text {ap }}$. Comparisons are summarized in Table 6 , where the fraction of brown carbon to total light absorption is listed along with typical $b_{\text {ap }}$ values from the various studies to provide some measure of the aerosol loading for each location. Most of the studies are substantially more polluted compared to conditions during our observations, but generally the fraction of brown carbon light absorption is similar. Hoffer et al. (2006) estimated that the contribution of HULIS to light absorption was only a few percent in Amazonia biomass burning aerosols at $532 \mathrm{~nm}$ and $35-50 \%$ at $300 \mathrm{~nm}$. Biomass burning aerosols are known to have high mass absorption efficiencies (Hecobian et al., 2010; Lack et al., 2012) and this may account for the high values. Observations from more highly polluted urban areas, including Xianghe (China) and Mexico City have fractional levels of brown carbon to total absorption of 30 to $40 \%$ at $400 \mathrm{~nm}$, that decreases to $10 \%$ at $550 \mathrm{~nm}$ (Barnard et al., 2008; Yang et al., 2009). Using column-integrated satellite data, Bahadur et al. (2012) also reported a similar fraction of brown carbon $(\sim 40 \%$ of the EC at $440 \mathrm{~nm}$ ) from 10 AERONET sites in CA. Cappa et al. (2012) reports lower fractions of brown carbon in Los Angeles, at $13 \%$ at $\sim 400 \mathrm{~nm}$, by directly measuring the en- hancement in aerosol absorption. Our results are similar, or slightly lower, compared to previous observations, but we were generally in cleaner environments.

\section{Summary}

Spectrophotometric measurements of fine particle extracts (Hecobian et al., 2010) have shown that light absorbing compounds with a strong wavelength dependence, and correlation with organic aerosol concentrations (Hecobian et al., 2010), are ubiquitous in the southeastern US. These chromophores are assumed to be components of the socalled brown carbon aerosol. In this study, a cascade impactor (MOUDI) was used to collect size-resolved aerosols on quartz filter substrates that were subsequently extracted in water and methanol and the light-absorption properties of the extracts analyzed. A total of six MOUDI samples were collected at locations that included a rural, central urban and roadside site. From these data, particle light absorption due solely from brown carbon was estimated using Mie calculations and the results were compared to optical absorption measurements made with Aethalometer and MAAP. Chromophores in MOUDI extracts at all sites were lognormally distributed and associated with the accumulation mode ( $\sim 0.5 \mu$ m geometric mean of aerodynamic diameter), an optically effective size. Mie-predicted light absorption by these particles was roughly two times greater than the bulk solution light absorption, over a range of wavelengths (350 to $571 \mathrm{~nm}$ ) at all sites. This is significantly higher than the small particle limit used in other studies when estimating particle light absorption from bulk solutions (factor of $\sim 0.7$ ).

Brown carbon was optically important at wavelengths less than roughly $600 \mathrm{~nm}$ with a fractional absorption relative to total absorption between 5 and $10 \%$ for water extracts and 20 and $40 \%$ for methanol extracts at $350 \mathrm{~nm}$. The highest 
relative absorption was measured at the rural site where $\mathrm{OC} / \mathrm{EC}$ ratios were highest, possibly indicating a secondary source for brown carbon that may be optically important.

Use of solvent extracts to estimate brown carbon $b_{\text {ap }}$ has the advantage that it can be isolated and the light absorption measured directly with high spectral resolution, in contrast to direct measurements of wavelength-dependent absorption that must infer a black carbon wavelength dependent absorption. However, assumptions associated with Mie calculations presented in this study may lead to substantial uncertainty, such as assuming the brown carbon is externally mixed with other light absorbers, like EC. This means the method does not consider possible light-absorption enhancements due to particle morphology, such as shell-core configurations (Bond et al., 2006; Cappa et al., 2012; Lack et al., 2010). However, the extent of shell-core optical effects is unclear. Recent measurements in Los Angeles suggest that despite coatings on soot, there was little light enhancement $(6 \%$ at $532 \mathrm{~nm}$, Cappa et al., 2012).

A multi-wavelength Aethalometer did not show evidence for enhanced light absorption at lower wavelengths. Although the levels of brown carbon absorption are within the Aethalometer measurement uncertainty (35\%), the discrepancy is worth exploring further to determine the cause; whether associated with the assumptions inherent in the solution absorption-Mie method applied here (i.e., the method possibly over-predicts brown carbon absorption) or related to Aethalometer operation/data interpretation limitations, limitations with our specific instrument. Many studies (e.g., Rizzo et al., 2011) have shown that Aethalometers detect brown carbon when the levels are high, such as in biomass burning plumes, but the instrument may have difficulty resolving brown from black carbon when relative levels are not greatly enhanced, a condition likely to be found frequently in the ambient troposphere. Repeating this study in an environment more heavily influenced by brown carbon would be useful.

\section{Appendix A}

Nomenclature

\begin{tabular}{|c|c|}
\hline$b_{\text {ap: }}$ & Light-absorption coefficient for fine particles $\left(\mathrm{M} \mathrm{m}^{-1}\right)$ \\
\hline BC: & Black carbon \\
\hline LOD: & limit of detection \\
\hline WSOC, OC, EC: & $\begin{array}{l}\text { water-soluble organic carbon, organic carbon and } \\
\text { elemental carbon }\left(\mu \mathrm{gC} \mathrm{m}{ }^{-3}\right)\end{array}$ \\
\hline$\rho:$ & Particle density, a value of $1.5 \mathrm{~g} \mathrm{~cm}^{-3}$ is used \\
\hline$\alpha / \rho:$ & Solution mass absorption efficiency, $\left(\mathrm{m}^{2} \mathrm{~g}^{-1}\right)$ \\
\hline$A_{\lambda}:$ & $\begin{array}{l}\text { Light absorbance measured by the spectrophotometer } \\
\text { (unitless) }\end{array}$ \\
\hline $\operatorname{Abs}(\lambda)$ : & $\begin{array}{l}\text { Light absorption measured in a solution at wavelength } \\
\lambda \\
\left(\mathrm{M} \mathrm{m}^{-1}\right)\end{array}$ \\
\hline $\mathrm{H}_{2} \mathrm{O} \_\mathrm{Abs}(\lambda)$ : & $\begin{array}{l}\text { Light absorption measured in water extract at } \\
\text { wavelength } \lambda\left(\mathrm{M} \mathrm{m}^{-1}\right)\end{array}$ \\
\hline $\mathrm{MeOH} \_\mathrm{Abs}(\lambda)$ & $\begin{array}{l}\text { Light absorption measured in methanol extract at } \\
\text { wavelength } \lambda\left(\mathrm{M} \mathrm{m}^{-1}\right)\end{array}$ \\
\hline$b_{\text {ap_EC }}:$ & $\begin{array}{l}\text { Mie predicted fine particle BC light absorption based on } \\
\text { MOUDI EC }\left(\mathrm{M} \mathrm{m}^{-1}\right) \text {, wavelength is specified in text. }\end{array}$ \\
\hline$b_{\text {ap }, \mathrm{H}_{2} \mathrm{O}}$ : & $\begin{array}{l}\text { Mie predicted fine particle brown carbon absorption } \\
\text { from MOUDI water extracts }\left(\mathrm{M} \mathrm{m}^{-1}\right) \text {, wavelength is } \\
\text { specified in text. }\end{array}$ \\
\hline$b_{\mathrm{ap}, \mathrm{MeOH}}:$ & $\begin{array}{l}\text { Mie predicted fine particle brown carbon absorption } \\
\text { from MOUDI methanol extracts }\left(\mathrm{M} \mathrm{m}^{-1}\right) \text {, wavelength } \\
\text { is specified in text. }\end{array}$ \\
\hline$b_{\text {ap_Aeth: }}$ & $\begin{array}{l}\text { Aethalometer }(7-\lambda) \text { fine particle }\left(\mathrm{PM}_{2.5}\right) \text { light } \\
\text { absorption with scattering correction }\left(\mathrm{M} \mathrm{m}^{-1}\right) \text {, wave- } \\
\text { length is specified in text. }\end{array}$ \\
\hline$b_{\text {ap_MAAP: }}$ & $\begin{array}{l}\text { Multi-angle absorption photometer (MAAP) fine } \\
\text { particle measurement of light absorption }\left(\mathrm{M} \mathrm{m}^{-1}\right) \text {, } \\
\text { operates at } 670 \mathrm{~nm} \text {. }\end{array}$ \\
\hline
\end{tabular}

Acknowledgements. This project was funded by NASA through contracts NNX12AB83G and NNX08AH80G and USEPA grant \# RD83479901, the latter as part of the Emory Georgia Tech Clean Air Center (SCAPE). The contents of this paper are solely the responsibility of the grantee and do not necessarily represent the official views of NASA or the USEPA. Further, these agencies do not endorse the purchase of any commercial products or services mentioned in the publication. The authors thank the SEARCH personnel for their many contributions in support of this work.

Edited by: R. Holzinger

\section{References}

Alexander, D. T. L., Crozier, P. A., and Anderson, J. R.: Brown carbon spheres in East Asian outflow and their optical properties, Science, 321, 833-836, 2008.

Andreae, M. O. and Gelencsér, A.: Black carbon or brown carbon? The nature of light-absorbing carbonaceous aerosols, Atmos. Chem. Phys., 6, 3131-3148, doi:10.5194/acp-6-3131-2006, 2006.

Bahadur, R., Praveen, P. S., Xu, Y. Y., and Ramanathan, V.: Solar absorption by elemental and brown carbon determined from spectral observations, P. Natl. Acad. Sci. USA, 109, 17366-17371, 2012.

Barnard, J. C., Volkamer, R., and Kassianov, E. I.: Estimation of the mass absorption cross section of the organic carbon component 
of aerosols in the Mexico City Metropolitan Area, Atmos. Chem. Phys., 8, 6665-6679, doi:10.5194/acp-8-6665-2008, 2008.

Bateman, A. P., Nizkorodov, S. A., Laskin, J., and Laskin, A.: Photolytic processing of secondary organic aerosols dissolved in cloud droplets, Phys. Chem. Chem. Phys., 13, 12199-12212, 2011.

Bohren, C. F. and Hoffman, D. R.: Absorption and Scattering of Light by Small Particles, John Wilely and Sons Inc, New York, 1998.

Bond, T. C.: Spectral dependence of visible light absorption by carbonaceous particles emitted from coal combustion, Geophys. Res. Lett., 28, 4075-4078, 2001.

Bond, T. C., Habib, G., and Bergstrom, R. W.: Limitations in the enhancement of visible light absorption due to mixing state, J. Geophys. Res., 111, D20211, doi:10.1029/2006JD007315, 2006.

Bond, T. C., Doherty, S. J., Fahey, D. W., Forster, P. M., Berntsen, T., DeAngelo, B. J., Flanner, M. G., Ghan, S., Kärcher, B., Koch, D., Kinne, S., Kondo, Y., Quinn, P. K., Sarofim, M. C., Schultz, M. G., Schulz, M., Venkataraman, C., Zhang, H., Zhang, S., Bellouin, N., Guttikunda, S. K., Hopke, P. K., Jacobson, M. Z., Kaiser, J. W., Klimont, Z., Lohmann, U., Schwarz, J. P., Shindell, D., Storelvmo, T., Warren, S. G., and Zender, C. S.: Bounding the role of black carbon in the climate system: A scientific assessment, J. Geophys. Res., 118, 5380-5552, doi:10.1002/jgrd.50171, 2013.

Bones, D. L., Henricksen, D. K., Mang, S. A., Gonsior, M., Bateman, A. P., Nguyen, T. B., 25 Cooper, W. J., and Nizkorodov, S. A.: Appearance of strong absorbers and fluorophores in limonene- $\mathrm{O}_{3}$ secondary organic aerosol due to $\mathrm{NH}_{4}^{+}$-mediated chemical aging over long time scales, J. Geophys. Res., 115, D05203, doi:10.1029/2009JD012864, 2010.

Cappa, C. D., Onasch, T. B., Massoli, P., Worsnop, D. R., Bates, T. S., Cross, E. S., Davidovits, P., Hakala, J., Hayden, K. L., Job son, B. T., Kolesar, K. R., Lack, D. A., Lerner, B. M., Li, S. M., Mellon, D., Nuaaman, I., Olfert, J. S., Petaja, T., Quinn, P. K., Song, C., Subramanian, R., Williams, E. J., and Zaveri, R. A.: Radiative Absorption Enhancements Due to the Mixing State of Atmospheric Black Carbon, Science, 337, 1078-1081, 2012.

Carrico, C. M., Bergin, M. H., Xu, J., Baumann, K., and Maring, H.: Urban aerosol radiative properties: Measurement during the 1999 Atlanta Supersite Experiment, J. Geophys. Res., 108, 8422, doi:10.1029/2001JD001222, 2003.

Chakrabarty, R. K., Moosmüller, H., Chen, L.-W. A., Lewis, K., Arnott, W. P., Mazzoleni, C., Dubey, M. K., Wold, C. E., Hao, W. M., and Kreidenweis, S. M.: Brown carbon in tar balls from smoldering biomass combustion, Atmos. Chem. Phys., 10, 63636370, doi:10.5194/acp-10-6363-2010, 2010.

Chang, J. L. and Thompson, J. E.: Characterization of colored products formed during irradiation of aqueous solutions containing $\mathrm{H}_{2} \mathrm{O}_{2}$ and phenolic compounds, Atmos. Environ., 44, 541-551, 2010.

Chen, Y. and Bond, T. C.: Light absorption by organic carbon from wood combustion, Atmos. Chem. Phys., 10, 1773-1787, doi:10.5194/acp-10-1773-2010, 2010.

Chow, J. C., Watson, J. G., Lowenthal, D. H., and Magliano, K. L.: Size-resolved aerosol chemical concentrations at rural and urban sites in Central California, USA, Atmos. Res., 90, 243-252, 2008.
Chung, C. E., Ramanathan, V., and Decremer, D.: Observationally constrained estimates of carbonaceous aerosol radiative forcing, P. Natl. Acad. Sci. USA, 109, 11624-11629, 2012.

De Haan, D. O., Corrigan, A. L., Smith, K.W., Stroik, D. R., Turley, J. J., Lee, F. E., Tolbert, M. A., Jimenez, J. L., Cordova, K. E., and Ferrell, G. R.: Secondary organic aerosol-forming reactions of glyoxal with amino acids, Environ. Sci. Technol., 43, 28182824, 2009.

Dinar, E., Riziq, A. A., Spindler, C., Erlick, C., Kiss, G., and Rudich, Y.: The complex refractive index of atmospheric and model humic-like substances (HULIS) retrieved by a cavity ring down aerosol spectrometer (CRD-AS), Faraday Discuss., 137, 279-295, 2008.

Duarte, R., Pio, C. A., and Duarte, A. C.: Spectroscopic study of the water-soluble organic matter isolated from atmospheric aerosols collected under different atmospheric conditions, Anal. Chim. Acta, 530, 7-14, 2005.

Eatough, D. J., Wadsworth, A., Eatough, D. A., Crawford, J. W., Hansen, L. D., and Lewis, E. A.: A multiple-system, multichannel diffusion denuder sampler for the determination of fineparticulate organic material in the atmosphere, Atmos. Environ. A-Gen., 27, 1213-1219, 1993.

Feng, Y., Ramanathan, V., and Kotamarthi, V. R.: Brown carbon: a significant atmospheric absorber of solar radiation?, Atmos. Chem. Phys., 13, 8607-8621, doi:10.5194/acp-13-8607-2013, 2013.

Fuzzi, S., Andreae, M. O., Huebert, B. J., Kulmala, M., Bond, T. C., Boy, M., Doherty, S. J., Guenther, A., Kanakidou, M., Kawamura, K., Kerminen, V.-M., Lohmann, U., Russell, L. M., and Pöschl, U.: Critical assessment of the current state of scientific knowledge, terminology, and research needs concerning the role of organic aerosols in the atmosphere, climate, and global change, Atmos. Chem. Phys., 6, 2017-2038, doi:10.5194/acp-62017-2006, 2006.

Hansen, D. A., Edgerton, E. S., Hartsell, B., and Jansen, J., Air quality measurements for the aerosol research and inhalation epidemiology study. J. Air Waste Manage., 56, 1445-1458, 2006.

Hecobian, A., Zhang, X., Zheng, M., Frank, N., Edgerton, E. S., and Weber, R. J.: Water-Soluble Organic Aerosol material and the light-absorption characteristics of aqueous extracts measured over the Southeastern United States, Atmos. Chem. Phys., 10, 5965-5977, doi:10.5194/acp-10-5965-2010, 2010.

Hoffer, A., Gelencsér, A., Guyon, P., Kiss, G., Schmid, O., Frank, G. P., Artaxo, P., and Andreae, M. O.: Optical properties of humic-like substances (HULIS) in biomass-burning aerosols, Atmos. Chem. Phys., 6, 3563-3570, doi:10.5194/acp-6-3563-2006, 2006.

Huang, X. F., Yu, J. Z., He, L. Y., and Hu, M.: Size distribution characteristics of elemental carbon emitted from Chinese vehicles: results of a tunnel study and atmospheric implications, Environ. Sci. Technol., 40, 5355-5360, 2006.

IPCC: Climate Change 2007: The Physical Science Basis. Contribution of Working Group I to the Fourth Assessment, Report of the Intergovernmental Panel on Climate Change, Cambridge University Press, Cambridge, UK, and New York, NY, USA, 996 pp., 2007.

Jacobson, M. Z.: Isolating nitrated and aromatic aerosols and nitrated aromatic gases as sources of ultraviolet light absorption, J. Geophys. Res.-Atmos., 104, 3527-3542, 1999. 
Jung, J., Kim, Y. J., Lee, K. Y., Cayetano, M. G., Batmunkh, T., Koo, J.-H., and Kim, J.: Spectral optical properties of longrange transport Asian dust and pollution aerosols over Northeast Asia in 2007 and 2008, Atmos. Chem. Phys., 10, 5391-5408, doi:10.5194/acp-10-5391-2010, 2010.

Kieber, R. J., Whitehead, R. F., Reid, S. N., Willey, J. D., and Seaton, P. J.: Chromophoric dissolved organic matter (CDOM) in rainwater, southeastern North Carolina, USA, J. Atmos. Chem., 54, 21-41, 2006.

Kirchstetter, T. W. and Thatcher, T. L.: Contribution of organic carbon to wood smoke particulate matter absorption of solar radiation, Atmos. Chem. Phys., 12, 6067-6072, doi:10.5194/acp-126067-2012, 2012.

Kirchstetter, T. W., Novakov, T., and Hobbs, P. V.: Evidence that the spectral dependence of light absorption by aerosols is affected by organic carbon, J. Geophys. Res.-Atmos., 109, D21208, doi:10.1029/2004JD004999, 2004.

Lack, D. A. and Cappa, C. D.: Impact of brown and clear carbon on light absorption enhancement, single scatter albedo and absorption wavelength dependence of black carbon, Atmos. Chem. Phys., 10, 4207-4220, doi:10.5194/acp-10-4207-2010, 2010.

Lack, D. A., Langridge, J. M., Bahreini, R., Brock, C. A., Middlebrook, A. M., and Schwarz, J. P.: Brown Carbon and Internal Mixing in Biomass Burning Particles, P. Natl. Acad. Sci. USA, 109, 14802-14807, doi:10.1073/pnas.1206575109, 2012.

Lan, Z. J., Chen, D. L., Li, X. A., Huang, X. F., He, L. Y., Deng, Y. G., Feng, N., and Hu, M.: Modal characteristics of carbonaceous aerosol size distribution in an urban atmosphere of South China, Atmos. Res., 100, 51-60, 2011.

Limbeck, A., Kulmala, M., and Puxbaum, H.: Secondary organic aerosol formation in the atmosphere via heterogeneous reaction of gaseous isoprene on acidic particles, Geophys. Res. Lett., 30, 1996, doi:10.1029/2003GL017738, 2003.

Lukacs, H., Gelencser, A., Hammer, S., Puxbaum, H., Pio, C., Legrand, M., Kasper-Giebl, A., Handler, M., Limbeck, A., Simpson, D., and Preunkert, S.: Seasonal trends and possible sources of brown carbon based on 2-year aerosol measurements at six sites in Europe, J. Geophys. Res., 112, D23S18, doi:10.1029/2006JD008151, 2007.

Moosmuller, H., Chakrabarty, R. K., and Arnott, W. P.: Aerosol light absorption and its measurement: a review, J. Quant. Spectrosc. Ra., 110, 844-878, 2009.

Nakayama, T., Matsumi, Y., Sato, K., Imamura, T., Yamazaki, A., and Uchiyama, A.: Laboratory studies on optical properties of secondary organic aerosols generated during the photooxidation of toluene and the ozonolysis of alpha-pinene, J. Geophys. Res.Atmos., 115, D24204, doi:10.1029/2010JD014387, 2010.

Nakayama, T., Sato, K., Matsumi, Y., Imamura, T., Yamazaki, A., and Uchiyama, A.: Wavelength and $\mathrm{NO}_{\mathrm{x}}$ dependent complex refractive index of SOAs generated from the photooxidation of toluene, Atmos. Chem. Phys., 13, 531-545, doi:10.5194/acp-13531-2013, 2013.

Nguyen, T. B., Lee, P. B., Updyke, K. M., Bones, D. L., Laskin, J., Laskin, A., and Nizkorodov, S. A.: Formation of nitrogen and sulfur-containing light-absorbing compounds accelerated by evaporation of water from secondary organic aerosols, J. Geophys. Res., 117, D01207, doi:10.1029/2011JD016944, 2012.

NIOSH: Elemental Carbon (Diesel Particulate): Method 5040, in: NIOSH Manual of Analytical Methods, edited by: Eller, P. M. and Cassinelli, M. E., National Institute for Occupational Safety and Health, Cincinnati, USA, 1996.

Park, R. J., Kim, M. J., Jeong, J. I., Youn, D., and Kim, S.: A contribution of brown carbonaerosol to the aerosol light absorption and its radiative forcing in East Asia, Atmos. Environ., 44, 14141421, doi:10.1016/j.atmosenv.2010.01.042, 2010.

Petzold, A. and Schönlinner, M.: Multi-angle absorption photometry - a new method for the measurement of aerosol light absorption and atmospheric black carbon, J. Aerosol Sci., 35, 421-441, 2004.

Qin, Y. and Mitchell, R. M.: Characterisation of episodic aerosol types over the Australian continent, Atmos. Chem. Phys., 9, 1943-1956, doi:10.5194/acp-9-1943-2009, 2009.

Rizzo, L. V., Correia, A. L., Artaxo, P., Procópio, A. S., and Andreae, M. O.: Spectral dependence of aerosol light absorption over the Amazon Basin, Atmos. Chem. Phys., 11, 8899-8912, doi:10.5194/acp-11-8899-2011, 2011.

Sandradewi, J., Prév^t, A. S. H., Alfarra, M. R., Szidat, S., Wehrli, M. N., Ruff, M., Weimer, S., Lanz, V. A., Weingartner, E., Perron, N., Caseiro, A., Kasper-Giebl, A., Puxbaum, H., Wacker, L., and Baltensperger, U.: Comparison of several wood smoke markers and source apportionment methods for wood burning particulate mass, Atmos. Chem. Phys. Discuss., 8, 8091-8118, doi:10.5194/acpd-8-8091-2008, 2008.

Sareen, N., Schwier, A. N., Shapiro, E. L., Mitroo, D., and McNeill, V. F.: Secondary organic material formed by methylglyoxal in aqueous aerosol mimics, Atmos. Chem. Phys., 10, 997-1016, doi:10.5194/acp-10-997-2010, 2010.

Shapiro, E. L., Szprengiel, J., Sareen, N., Jen, C. N., Giordano, M. R., and McNeill, V. F.: Light-absorbing secondary organic material formed by glyoxal in aqueous aerosol mimics, Atmos. Chem. Phys., 9, 2289-2300, doi:10.5194/acp-9-2289-2009, 2009.

Sokolik, I. N. and Toon, O. B.: Incorporation of mineralogical composition into models of the radiative properties of mineral aerosol from UV to IR wavelengths, J. Geophys. Res., 104, 9423-9444, 1999.

Sun, H., Biedermann, L., and Bond, T. C.: The color of brown carbon: A model for ultraviolet and visible light absorption by organic carbon aerosol, Geophys. Res. Lett., 34, L17813, doi:10.1029/2007GL029797, 2007.

Updyke, K. M., Nguyen, T. B., and Nizkorodov, S. A.: Formation of brown carbon via reactions of ammonia with secondary organic aerosols from biogenic and anthropogenic precursors, Atmos. Environ., 63, 22-31, 2012.

Weingartner, E., Saathoff, H., Schnaiter, M., Streit, N., Bitnar, B., and Baltensperger, U.: Absorption of light by soot particles: determination of the absorption coefficient by means of aethalometers, J. Aerosol Sci., 34, 1445-1463, 2003.

Yan, F., Winijkul, E., Jung, S., Bond, T. C., and Streets, D. G.: Global emission projections of particulate matter (PM): I. Exhaust emissions from on-road vehicles, Atmos. Environ., 45, 4830-4844, 2011.

Yang, M., Howell, S. G., Zhuang, J., and Huebert, B. J.: Attribution of aerosol light absorption to black carbon, brown carbon, and dust in China - interpretations of atmospheric measurements during EAST-AIRE, Atmos. Chem. Phys., 9, 2035-2050, doi:10.5194/acp-9-2035-2009, 2009.

Zhang, X., Lin, Y.-H., Surratt, J. D., Zotter, P., Prévôt, A. H. S., and Weber, R. J.: Light-absorbing soluble organic aerosol in Los 
Angeles and Atlanta: A contrast in secondary organic aerosol, Geophys. Res. Lett., 38, L21810, doi:10.1029/2011GL049385, 2011.
Zhang, X. L., Lin, Y. H., Surratt, J. D., and Weber, R. J.: Sources, composition and absorption Angström exponent of light-absorbing organic components in aerosol extracts from the Los Angeles Basin, Environ. Sci. Technol., 47, 3685-3693, doi:10.1021/es305047b, 2013. 